\title{
Interferon- $\gamma$-central mediator of protective immune responses against the pre-erythrocytic and blood stage of malaria
}

\author{
Matthew B. B. McCall and Robert W. Sauerwein ${ }^{1}$ \\ Department of Medical Microbiology, Radboud University Nijmegen Medical Centre, Nijmegen, The Netherlands \\ RECEIVED MARCH 10, 2010; REVISED JUNE 2, 2010; ACCEPTED JUNE 10, 2010. DOI: 10.1189/jlb.0310137
}

\begin{abstract}
Immune responses against Plasmodium parasites, the causative organisms of malaria, are traditionally dichotomized into pre-erythrocytic and blood-stage components. Whereas the central role of cellular responses in pre-erythrocytic immunity is well established, protection against blood-stage parasites has generally been ascribed to humoral responses. A number of recent studies, however, have highlighted the existence of cellular immunity against blood-stage parasites, in particular, the prominence of IFN- $\gamma$ production. Here, we have undertaken to chart the contribution of this prototypical cellular cytokine to immunity against pre-erythrocytic and blood-stage parasites. We summarize the various antiparasitic effector functions that IFN- $\gamma$ serves to induce, review an array of data about its protective effects, and scrutinize evidence for any deleterious, immunopathological outcome in malaria patients. We discuss the activation and contribution of different cellular sources of IFN- $\gamma$ production during malaria infection and its regulation in relation to exposure. We conclude that IFN- $\gamma$ forms a central mediator of protective immune responses against pre-erythrocytic and blood-stage malaria parasites and identify a number of implications for rational malaria vaccine development. J. Leukoc. Biol. 88: 1131-1143; 2010.
\end{abstract}

\section{Introduction}

IFN- $\gamma$ is the only type-II IFN and is the prototypical Th1 cytokine, inducing cell-mediated immunity by promoting Th1 over Th2 differentiation of $\mathrm{T}$ cells, inducing IgG class-switching to cytophilic isotypes, and activating phagocytes (reviewed in ref. [1]). It is produced predominantly by lymphocytes, including NK, NKT cells, $\gamma \delta \mathrm{T}$, and $\alpha \beta \mathrm{T}$ cells, but may also be produced by cells of the myeloid lineage $[2,3]$. Its induction is largely dependent on IL-12 and IL-18 production by activated myeloid APCs $[4,5]$, in addition to signals directly activating lymphocytes themselves.

Abbreviations: $\mathrm{ADCl}=$ antibody-dependent cellular inhibition, $\mathrm{mDC}=$ myeloid $\mathrm{DC}, \mathrm{pRBC}=$ parasitized $\mathrm{RBC}, \mathrm{SM}=$ severe malaria, TRAP=thrombospondinrelated anonymous protein, $\mathrm{UM}=$ uncomplicated malaria
IFN- $\gamma$ is an important mediator of the immune response against intracellular (myco)bacteria and some viruses [6-8] but is also involved in protection against intra- and extracellular protozoan parasites such as Leishmania spp. [9], Trypanosoma cruzi [10], and Toxoplasma gondii [11]. In this review, we will focus on the involvement of IFN- $\gamma$ in immune responses against malaria.

Malaria is caused by protozoan parasites of the genus Plasmodium, and Plasmodium falciparum in particular has major clinical importance for human disease at a global scale. Plasmodium parasites have a complicated, multistage lifecycle involving intra- and extracellular stadia in an Anopheline mosquito vector and a vertebrate host (Fig. 1).

By convention, immune responses in malaria are dichotomized into pre-erythrocytic responses (directed against sporozoites and liver-stage parasites) and blood-stage responses (directed against merozoites and intraerythrocytic parasites). Whereas humoral (antibody) responses against extracellular sporozoite stages are well documented $[13,14]$, pre-erythrocytic immunity is generally considered to consist largely of cellular responses against infected hepatocytes, which inhibit intracellular parasite development through the induction of reactive nitrogen intermediates (reviewed in ref. [15]). In contrast, humoral responses against extracellular merozoites and intraerythrocytic parasites $(\mathrm{pRBC})$ have traditionally been considered the most important component of blood-stage immunity [16-18]. T cell responses against pRBC remain less well understood, partly because erythrocytes lack MHC class I or II presentation capacity. Nevertheless, cellular responses against $\mathrm{pRBC}$ have been suggested to contribute to protection in humans in the absence of antibodies [19, 20]. Finally, monocyte/macrophage-mediated responses, in particular phagocytosis (e.g., ref. [21]), and ADCI (e.g., ref. [22]), also form an important component of blood-stage immunity.

Given the above, IFN- $\gamma$ likely forms an important component of immunity against both stages of malaria infection. Indeed, IFN- $\gamma$ plays a plethora of roles in malaria, functioning equally as an inducer and effector of innate and adaptive im-

1. Correspondence: Department of Medical Microbiology 268, Radboud University Nijmegen Medical Centre, P.O. Box 9101, 6500 HB Nijmegen, The Netherlands. E-mail: r.sauerwein@mmb.umcn.nl 


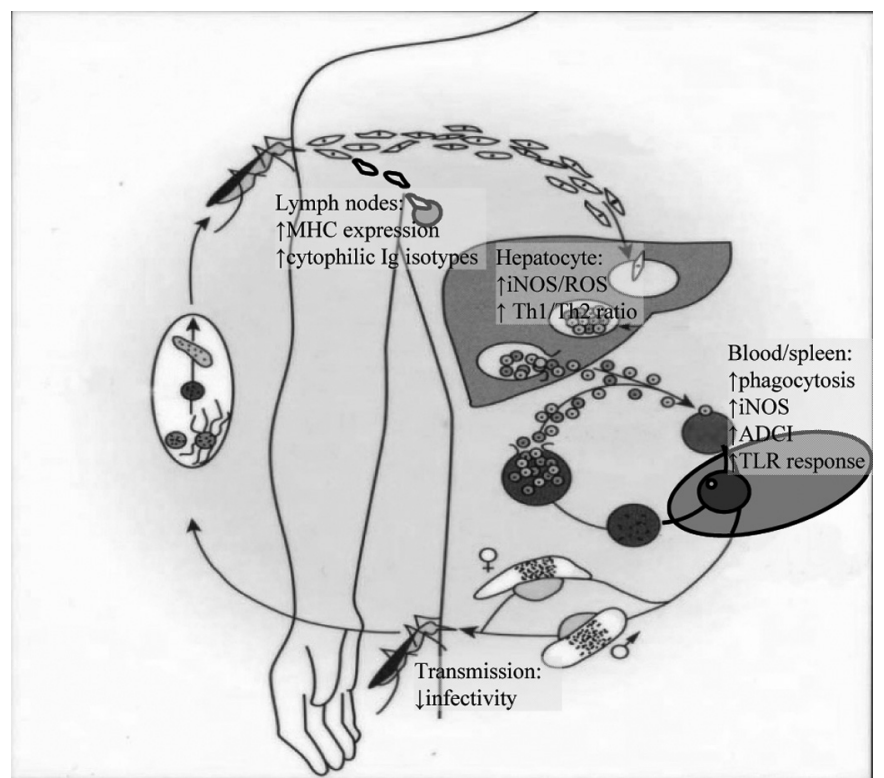

Figure 1. Lifecycle of malaria parasites and effector functions of IFN- $\boldsymbol{\gamma}$. Infective sporozoite-stage parasites are unwittingly injected into the skin of human hosts by blood-feeding mosquitoes, where a proportion is trapped in draining lymph nodes, but the remainder migrates quickly to the liver. These sporozoites invade hepatocytes, in which they mature and multiply intracellularly over $6-7$ days without causing symptoms. Once fully ripe, these liver-stage schizonts rupture, releasing merozoites into the bloodstream, which invade erythrocytes (RBCs) immediately. These intraerythrocytic parasites multiply asexually over roughly $48 \mathrm{~h}$ into blood-stage schizonts, which again rupture, releasing a second generation of merozoites that in turn invade new RBCs. It is this exponential multiplication cycle that is responsible for the clinical symptoms and potentially severe complications of malaria. A small number of blood-stage parasites develop into male and female gametocyte forms, which can be taken up by a second blood-feeding mosquito. Within the mosquito, these gametes undergo sexual replication, eventually resulting in a new generation of infective sporozoites. Various effector functions of IFN- $\gamma$, enhancing immunological recognition and elimination of the parasite's different lifecycle stages, are indicated. This figure is modified from ref. [12] with permission.

mune responses (Table 1) throughout the parasite lifecycle (Fig. 1). It could even be argued that IFN- $\gamma$ forms the central determinant of all immunological pathways involved in protection against malaria.

However, what then is the hard evidence for a protective role of IFN- $\gamma$ responses? What host and parasite factors determine those responses, and how can we exploit those factors to design an effective malaria vaccine rationally? In this review, we first focus on the wealth of evidence for the protective role of IFN- $\gamma$ responses and critically discuss any evidence for their possible immunopathological (side-) effects. Next, we examine the various potential cellular sources of IFN- $\gamma$, their differing requirements for activation, and their relative contribution to total IFN- $\gamma$ production during pre-erythrocytic and blood-stage infection. Finally, we consider the relationship between exposure and IFN- $\gamma$ responses and discuss immunoregulation by the malaria parasite. We conclude by identifying a number of implications arising from (gaps in) our current understanding of IFN- $\gamma$ responses, with particular regard to rational malaria vaccine development. Where possible, we present direct evidence from human studies of $P$. falciparum infection, which we supplement with data from in vitro and murine malaria models.

\section{EVIDENCE FOR PROTECTION}

As a result of distinct biological, immunological, and pathological characteristics for each stage (Fig. 1), most research into immunological correlates of protection in malaria has focused on pre-erythrocytic or erythrocytic stages separately. A wealth of data about both stages exists from murine malaria models and human studies. Here, we will briefly discuss the consensus derived from murine immunological studies and focus primarily on human data, including experimental malaria infections, cross-sectional and longitudinal field studies, and efficacy data from vaccine studies.

\section{Pre-erythrocytic stages}

Pre-erythrocytic protection can be induced in murine malaria models by various immunization strategies, including irradiated sporozoites, recombinant peptide, or nucleic-acid vaccines. Although immunological effector mechanisms vary slightly between approaches and between inbred mouse strains (e.g., refs. [24, 43-48]), the core elements tend to consist of $\mathrm{CD}^{+}$and/or $\mathrm{CD}^{+} \mathrm{T}$ cells and IFN- $\gamma$-mediated responses against infected hepatocytes (reviewed in ref. [15]). Indeed, protection against pre-erythrocytic malaria in naive mice, rats, and monkeys can also be induced by simply injecting exogenous IFN- $\gamma[23,49]$ or IL-12 [50, 51].

Some of the most compelling evidence for the protective role of IFN- $\gamma$ responses in humans comes from experimental malaria infections. The strength of these studies lies in the tight control exercised over previous exposure, timing, and measure of infection, factors that often confound field-based studies. Following a primary infection, high IFN- $\gamma$ responses are associated with reduced asexual parasite multiplication rates, although eventually, all volunteers do develop patent parasitemia [52].

Since the days of malaria therapy, however, scientists have known that sterile immunity against malaria can be induced in humans unexposed previously. The best-studied approach has been through inoculation of irradiated sporozoites by repeated mosquito bites [53]. These radiation-attenuated sporozoites arrest during the liver stage and induce humoral (e.g., ref. [54]) and $\mathrm{CD}^{+}$[55] and $\mathrm{CD}^{+}$[56] cytotoxic T cell and IFN- $\gamma$ responses against sporozoites and liver-stage antigens $[57,58]$. Nevertheless, multiple rounds of immunization, equating to at least 1000 infected mosquito bites, are required to generate sterile protection in $>90 \%$ of the volunteers.

In an attempt to improve upon this protocol, we recently immunized volunteers with patent sporozoites under cover of the blood schizonticidal drug chloroquine, which leaves development of liver stages unaffected [20]. This approach exposes volunteers' immune systems to the full course of intrahepatic development, in addition to the first cycle of intraerythrocytic 
Table 1. Effects of IFN- $\gamma$ on Innate and Adaptive Immune Responses against Malaria

Function

References

Innate immune responses

Increased production of reactive nitrogen species (iNOS) by liver cells against intrahepatic parasites

Increased production of reactive oxygen $\left(\mathrm{H}_{2} \mathrm{O}_{2}\right)$ and nitrogen species (iNOS) by monocytes against blood-stage parasites

Enhanced phagocytosis of merozoites and pRBC

Inhibition of gametocyte infectivity to mosquitoes

Interplay between innate and adaptive systems

Proinflammatory priming of TLR responses

Up-regulation of MHC class I and II expression

Enhanced ADCI against blood-stage parasites

Adaptive immune responses

Increased Th1/Th2 ratio amongst $\mathrm{T}$ cells

Class-switching by B cells to cytophilic antibody isotypes

Enhanced induction of cellular (central) memory responses

development. Following 3 rounds of immunization (totalling 36-45 infectious bites), sterile protection against subsequent patent sporozoite challenge was achieved in all volunteers, none of whom developed detectable blood-stage parasitemia. Interestingly, robust cellular responses were detected in all immunised volunteers, consisting of pluripotent effector memory $\mathrm{T}$ cells that produced IFN- $\gamma$, in addition to TNF- $\alpha$ and IL-2 in response to $\mathrm{pRBC}$ in vitro, suggesting an important role for stage-transcending cellular immunity. In contrast, antibody responses against pre-erythrocytic and blood-stage antigens were detectable at low titers in only 8 of 10 and 3 of 10 volunteers, respectively [20].

Many field studies in malaria-endemic areas have sought to correlate (cellular) immune responses with protection against malaria. The most robust of these included multiple assay points and a prospective follow-up, whereas cross-sectional surveys and other single-point measurements can suffer from the commonly observed temporal variability in individual immune responses to malaria [59-61]. Furthermore, it can prove difficult sometimes to differentiate between pre-erythrocytic and blood-stage protection, particularly in clinical studies.

Initial studies measuring only plasma IFN- $\gamma$ levels in malaria patients found a correlation with protection against reinfection [62], but results from subsequent studies remained equivocal, failing [63-65] or succeeding [66-69] to demonstrate an association between clinical protection and IFN- $\gamma$ responses to selected pre-erythrocytic antigens. The explanation for these discrepancies may be related to obvious differences in setting, endemicity, age, and assay techniques. Alternatively, this outcome may represent an insufficiently measurable effect of such individual responses amidst the full spectrum of antiparasite immune reactivity. Simple ex vivo assays, representing effector (memory) responses, may be less representative of in vivo protection than cultured assays representing central memory responses, as has been shown for the vaccine candidate TRAP (ref. [70] vs. ref. [71], respectively) and circumsporozoite protein [69].

Associations between IFN- $\gamma$ responses to individual preerythrocytic antigens and clinical protection have also been studied in phase IIa and phase IIb malaria vaccine trials, in particular in the context of RTS,S, a pre-erythrocytic vaccine candidate containing epitopes from the circumsporozoite protein coupled to hepatitis B surface antigen particles in a proprietary oil-in-water adjuvant [72]. In an initial phase IIa trial, prolonged IFN- $\gamma$ responses by $\mathrm{CD}^{+}$and $\mathrm{CD} 8^{+} \mathrm{T}$ cells against the circumsporozoite protein associated with protection upon experimental challenge [73]. Although in another study only a trend was seen for higher circumsporozoite protein-specific ex vivo and cultured ELISPOT IFN- $\gamma$ responses in PBMC from protected volunteers [74], a review of subsequent phase IIa trials confirmed that higher IFN- $\gamma$ ELISPOT counts were observed consistently in protected volunteers [75]. Results from phase IIb field studies have been slightly less forthcoming, but nevertheless, PBMC-cultured IFN- $\gamma$ ELISPOT responses to 1 circumsporozoite protein epitope were associated with protection in Gambian adults [69], and a trend was seen for higher $\mathrm{CD}^{+}$IFN- $\gamma$ responses to circumsporozoite protein in protected Mozambiquan infants [76].

A phase IIa trial of liver-stage antigen-1 [77] in a similar adjuvant system induced robust IFN- $\gamma$ recall responses but unfortunately failed to induce protection against challenge in malaria-naivve volunteers. More success has been achieved with the vaccine candidate malaria epitope-TRAP, administered in the form of prime-boost regimens with attenuated vaccinia and adenoviral vectors. This vaccine has been shown to induce protection against challenge in a proportion of naïve volunteers, which correlates with IFN- $\gamma$ responses by cultured, but not ex vivo, ELISPOT [78, 79].

Thus, sufficiently strong IFN- $\gamma$ responses against selected, pre-erythrocytic antigens are associated with protection against (clinical) malaria episodes.

\section{Blood stage}

Cellular responses, including IFN- $\gamma$, are also important in controlling blood-stage parasites in murine models (reviewed in refs. $[80,81])$. Perhaps the most clear-cut evidence for this arises from infections in IFN- $\gamma^{-/-}[28,82,83]$ and IFN- $\gamma \mathrm{R}^{-/-}$ mice [84], who fail to control the initial wave of parasite multiplication following blood-stage challenge and succumb rapidly to hyperparasitemia. A similar failure to control parasitemia is 
observed in immunocompetent animals, in which IFN- $\gamma$ is depleted during infection [85-87].

To assess blood stage-specific protection in human volunteers, Pombo and colleagues [19] infected volunteers repeatedly with submicroscopic inocula of blood-stage parasites, which were subsequently drug-cleared before they became patent. These inoculations induced strong $\mathrm{CD} 4^{+} \mathrm{T}$ cell-mediated responses against $\mathrm{pRBC}$, including proliferation and IFN- $\gamma$ production, but no measurable antibody responses. The volunteers were subsequently found to be protected against a similar blood-stage challenge. This landmark study was thereby the first to demonstrate a protective effect of cell-mediated immune responses against blood-stage malaria parasites in humans [19], although a concomitant effect of residual circulating antimalarial drug concentrations could not be excluded [88].

Several field studies have also assessed cellular correlates of protection against blood-stage malaria by measuring IFN- $\gamma$ production to whole parasites (i.e., live pRBC or pRBC lysate) in whole blood or PBMC assays. With the exception of 1 small retrospective study [89], other prospective studies have consistently found $\mathrm{pRBC}$-induced IFN- $\gamma$ responses to be associated with reduced risk of fever and clinical malaria episodes [9092]. Similarly, we recently found pRBC-specific IFN- $\gamma$ responses to correlate with protection against parasitemia at an ethnic and individual level [93]. Associations between protection and IFN- $\gamma$ responses to individual (vaccine candidate) blood-stage antigens are not conclusive: although most studies failed [94-99], two other studies did show such associations $[66,100]$.

In conclusion, broad, antiparasite IFN- $\gamma$ responses, but not necessarily responses to individual blood-stage antigens, are associated with protection against (clinical) malaria episodes.

\section{Evidence for IFN- $\gamma$ in inflammation and immunopathology}

Clinical malaria is characterized by strong, proinflammatory responses, in particular the production of IL-1 $\beta$, IL-6, and TNF- $\alpha$ endogenous pyrogens, which induce the disease's characteristic of high fever. Overproduction of these cytokines has also been implicated in the immunopathology underlying various forms of SM, in particular cerebral malaria [101-105]. IFN- $\gamma$ in itself is not a pyrogen but can induce downstream pyrogenic cytokines, in addition to its many other immunomodulatory functions (Table 1). IFN- $\gamma$ has been shown to be involved in many [83, 106-109] but not all [110-113] murine models of cerebral malaria, and similar discrepancies exist for other forms of severe disease in rodent models [114-116]. What then is the evidence that IFN- $\gamma$ contributes to pyrexia and more importantly, to immunopathology in human malaria? Studies in malaria-naïve volunteers have indeed indicated (temporal) correlations between IFN- $\gamma$ responses and fever during experimental infection [52, 117]. Most (but not all [118]) case-control studies have similarly measured higher plasma IFN- $\gamma$ levels in symptomatic malaria patients compared with healthy or uninfected controls [119-121]. Furthermore, ex vivo IFN- $\gamma$ responses to blood-stage exoantigens [95] but not whole
pRBC [90] have prospectively been associated with susceptibility to pyretic malaria episodes. Thus, it seems likely that IFN- $\gamma$ does indeed contribute to inflammation and fever in malaria.

However, the evidence is less clear-cut for an association between IFN- $\gamma$ responses per se (as opposed to TNF- $\alpha$ and other proinflammatory cytokines) and manifestations of SM. Whereas several case-control studies found higher plasma IFN- $\gamma$ levels in SM compared with UM patients [122-126], various similar studies have found higher plasma levels of TNF- $\alpha$ [120, 127-130], IL-2R [131], IL-6 [127, 132], IL-1 $\alpha$ [128], or IL-1 $\beta$ [130] but never IFN- $\gamma$ in SM compared with UM patients. Furthermore, plasma levels of IL-12 [130, 133136] and IL-18 [134-136], which induce IFN- $\gamma$, have been found to be lower in SM than UM patients. Finally, a higher proportion of children with UM registered ex vivo IFN- $\gamma$ responses to malaria antigens, although absolute cytokine concentrations did not differ between UM and SM groups [66].

Any association between IFN- $\gamma$ and specific outcomes of SM remains similarly unclear: whereas plasma levels of IFN- $\gamma$ were lower in Indian patients with cerebral malaria than in patients with other forms of SM or UM [130], no such difference was seen in Burundi [137]. Postmortem studies have identified [138] and failed to identify [139] elevated IFN- $\gamma$ in the brains of cerebral malaria victims. The largest study to date in 287 Vietnamese patients with severe disease found plasma levels of TNF- $\alpha$ and IL-6 and IL-10 but not IFN- $\gamma$ to be positively correlated with the risk of death. Amongst patients with various manifestations of severe disease, high plasma IFN- $\gamma$ levels were particularly associated with hyperparasitemia and to a lesser extent with jaundice and shock, but not with renal failure and were negatively correlated with cerebral malaria [140]. Similarly, amongst Malian children with cerebral malaria, plasma IFN- $\gamma$ levels and the prevalence of the IFN- $\gamma$ promoter polymorphism 183G/T (which increases gene transcription [141, 142]) were lower than in matched UM controls [143].

Whereas some studies have found elevated plasma levels of IFN- $\gamma$ associated with (severe) malarial anemia [144, 145], other studies found no such association [90, 146] or even an inverse relationship between IFN- $\gamma$ responses and anemia [147]. Finally, IFN- $\gamma$ has been associated with adverse pregnancy outcome [148, 149], particularly in primigrivdae, but again, this has not been a universal finding [150, 151].

Some caution must be exercised when interpreting these findings, as cross-sectional immunological measurements, in particular plasma cytokine levels during infection, may represent both cause and effect of clinical presentation. Thus, although IFN- $\gamma$ responses appear to be correlated with symptomatic infection, the relationship between IFN- $\gamma$ responses and manifestations of severe disease appears to be much more complex and will require further dissection. Nevertheless, the greater part of evidence from human studies would at least suggest a negative association between IFN- $\gamma$ responses and cerebral malaria. 


\section{HOST AND PARASITE FACTORS DETERMINE THE MAGNITUDE OF IFN- $\gamma$ RESPONSES AGAINST MALARIA}

\section{Cellular sources of IFN- $\gamma$ against different parasite life stages}

$\alpha \beta T$ cells, $\gamma \delta \mathrm{T}$ cells, NKT cells, and NK cells have variously been shown to produce IFN- $\gamma$ in response to Plasmodium parasites, although mechanisms of activation differ amongst these lymphocyte subsets, and their relative magnitude varies between parasite stages. Delineating these various pathways and their potential contribution to the total magnitude of IFN- $\gamma$ production is an important step toward understanding protective cellular immunity against malaria.

Classical "adaptive" $(\alpha \beta) \mathrm{T}$ cell responses are dependent on presentation of cognate antigen in the context of MHC class I or II molecules. $\mathrm{CD}^{+} \mathrm{T}$ cells recognize parasite-infected hepatocytes in the context of MHC class I presentation [44], leading to IFN- $\gamma$ production (e.g., ref. [152]), but first require priming by cross-presenting DCs in skin-draining lymph nodes $[153,154] . \mathrm{CD}^{+} \mathrm{T}$ cells also recognize pre-erythrocytic antigen in MHC class II context $[56,155,156]$. In addition to $\alpha \beta$ T cells, $\gamma \delta \mathrm{T}$ responses have been shown to contribute to liver-stage protection [157], and NKT cells can inhibit intrahepatic parasite development through IFN- $\gamma$ production [158]. Finally, NK cell IFN- $\gamma$ responses have been demonstrated against sporozoites [159] and parasitized hepatocytes [47, 160]. Thus, considerable redundancy appears to exist between cellular sources of IFN- $\gamma$ against pre-erythrocytic parasite stages, but the relative importance of these various lymphocyte subsets for protection in humans remains unresolved (reviewed in ref. [15]).

The cellular source of IFN- $\gamma$ responses to intraerythrocytic parasites appears at first to form an immunological blind spot. Whereas $\mathrm{CD}^{+} \mathrm{T}$ cells may recognize malaria antigen phagocytosed and presented on MHC II molecules by professional APCs, it was generally believed that $\mathrm{CD} 8^{+} \mathrm{T}$ cells cannot respond to pRBC. However, it was demonstrated recently in murine malaria models that blood-stage infection can generate parasite-specific $\mathrm{CD}^{+}$(cytotoxic) T cell responses, following cross-presentation by DCs [161, 162]. Intriguingly, it has been suggested that such blood-stage infection-induced $\mathrm{CD} 8^{+} \mathrm{T}$ cells may be involved in protection against liver-stage but not blood-stage infection [48]. Furthermore, $\mathrm{CD}^{+}$and $\mathrm{CD} 8^{+}$ pRBC-responding $\mathrm{T}$ cell clones have been isolated from human exposed previously [163].

$\gamma \delta \mathrm{T}$ cells too can recognize malaria antigens in the MHC class II $[164,165]$ or I [166] context, inducing proliferation and IFN- $\gamma$ production [167-169]. Some studies have suggested this response to be IL-2-dependent [166, 170, 171], implying a crucial accessory role for $\mathrm{CD}^{+} \mathrm{T}$ cells. However, the $\gamma \delta \mathrm{TCR}$ is also capable of recognizing nonpeptide antigens directly, particularly phosphoantigens, without MHC presentation. Thus, in contrast to $\alpha \beta \mathrm{T}$ cells and NK cells, $\gamma \delta \mathrm{T}$ cells can respond to pRBC in the absence of APCs [172, 173], although supplementation with APC-derived cytokines, e.g., IL-12, can augment $\gamma \delta \mathrm{T}$ cell IFN- $\gamma$ production further (reviewed in ref. [174]).
NK cells are considered innate lymphocytes as the first line of defense (reviewed in ref. [175]) and potent early producers of IFN- $\gamma$ in response to $\mathrm{pRBC}$ in vitro, for which they are dependent on IL-12 and IL-18 [176]. Myeloid APCs presumably form the source of the required IL-12 and IL-18, as the presence of these cells is required for IFN- $\gamma$ response by NK cells in vitro. Exactly which APC subsets are required remains somewhat unclear: some authors report that only monocytes suffice [177], whereas others also demonstrate this ability in mDCs [178]. The latter group further demonstrated the additional requirement of contact-dependent signals between APCs and NK cells [178]. Besides these accessory signals, NK cells must make direct cell contact with pRBC for an IFN- $\gamma$ response $[179,180]$. Intriguingly, heterogeneity in killer cell Ig-like receptors appears to correlate with NK IFN- $\gamma$ responses to pRBC $[179,181]$, although this does not necessarily mean that these receptors interact directly with $\mathrm{pRBC}$, which lack MHC class I molecules. More recently, it was also proposed that NK cells recognize the parasite surface protein $P$. falciparum erythrocyte membrane protein-1 via another NKR, NKp30 [182]. Finally, IFN- $\gamma$ induction by pRBCs in NK cells is also IL-2-dependent [178] but needs additional helper signals from $\mathrm{CD}^{+} \mathrm{T}$ cells (unpublished results). An overview of the various cellular pathways to IFN- $\gamma$ against different parasite stages is provided in Fig. 2.

The relative contribution of these different lymphocyte subsets to total IFN- $\gamma$ production in response to pRBC needs to be explored further, however. In in vitro stimulation experiments with PBMC from malaria-naive donors, the majority of IFN- $\gamma$-producing cells has, respectively, been identified as NK cells $[176,177], \alpha \beta$ T cells $[171,185]$, and $\gamma \delta$ T cells [168], including intriguing NK-like $\gamma \delta$ T cells [169]. Whether these inconsistencies represent differences between donors or in experimental setups is not fully clear, although it is evident that in most donors, all three subsets do contribute to the total response. Less still is known about in vivo sources of IFN- $\gamma$ during malaria infection in humans or in recall responses from previously exposed donors. Plasma samples taken from malarianaïve volunteers undergoing experimental malaria infection revealed soluble granzyme induction in addition to IFN- $\gamma$ and other cytokines, suggesting an early role of NK cells [186], and during and following infection, not only $\alpha \beta$ T cells but also $\gamma \delta \mathrm{T}$ cells and NK cells contributed to the overall increase in in vitro IFN- $\gamma$ responses against $\mathrm{pRBC}$ (unpublished results). In a naturally exposed, healthy pediatric population, the majority of IFN- $\gamma$-producing lymphocytes was NK-like $\gamma \delta \mathrm{T}$ cells [91], and more data will be required to identify the different cell sources of IFN- $\gamma$ in (non-)immune malaria patients.

\section{Dynamics of IFN- $\gamma$ responses in relation to exposure}

A second factor affecting the magnitude of IFN- $\gamma$ responses against malaria is their modulation in relation to exposure. Low-level IFN- $\gamma$ responses to $\mathrm{pRBC}$ have been demonstrated repeatedly in malaria-naïve donors [169, 176, 187-190] and have variously been ascribed to innate responses, nonspecific polyclonal responses to superantigens, or cross-reactive responses by $\mathrm{T}$ cells primed by environmental antigens (discussed in ref. [191]). In contrast, recall responses are mark- 
A

Figure 2. Induction and cellular sources of IFN- $\gamma$ against various malaria parasite stages. (A) NK cells recognize free sporozoites directly [159]. (B) In skin-draining lymph nodes, sporozoites invade or are taken up by DCs, which in turn, prime $\mathrm{CD} 4^{+} \mathrm{T}$ cells (presentation on MHC-II) [156] and $\mathrm{CD}^{+} \mathrm{T}$ cells (cross-presentation on MHC-I) $[153,154]$. (C) Primed CD8 ${ }^{+} \mathrm{T}$ cells recognize infected hepatocytes directly $[44,152]$; primed $\mathrm{CD} 4^{+} \mathrm{T}$ cells respond to antigen presented by local APCs [56, 155, 156]. NK cells are activated in a bystander manner [47, 160]. (D) In blood or spleen, $\gamma \delta \mathrm{T}$ cells recognize pRBC-phosphorylated antigens directly without the need for APC presentation $[172,173]$. APCs (monocytes and/or mDCs) recognize pRBC ligands through PRRs (e.g., hemozoin [183] and/or associated parasite DNA [184] via TLR-9). CD4 ${ }^{+}$ and $\mathrm{CD}^{+}$recognize $\mathrm{pRBC}$ antigens presented by $\mathrm{DCs}$ in, respectively, MHC-II [163] and (cross-presented) MHC-I context [161, 162]. NK cells recognize pRBC directly [179] but require help from APCs and probably also $\mathrm{T}$ cells for full activation $[177,178]$.
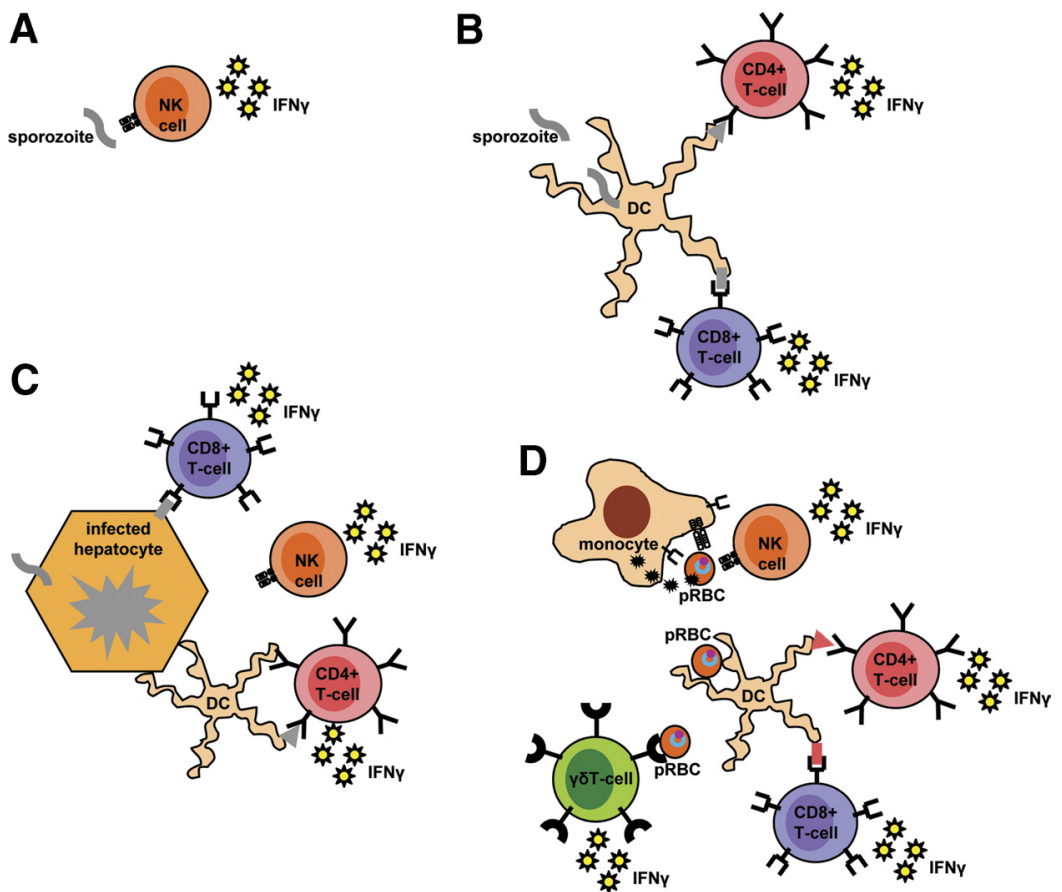

edly increased in malaria patients following a first clinical episode [192-195]. Indeed, even subclinical infections are sufficient to induce robust IFN- $\gamma$ responses to $\mathrm{pRBC}$ in previously naïve donors [19, 20, 42].

In general, immune responses to malaria are commonly believed to be short-lived following exposure, based mainly on the short half-life of specific antibodies [196-198] (reviewed in ref. [199]), an explanation that is often offered for the slow development of immunity. It would appear that IFN- $\gamma$ responses to individual antigens are indeed relatively short-lived, i.e., declining within a few years of exposure [200, 201], or at least unstable [59-61]. However, even before the characterization of IFN- $\gamma$, Wyler and Oppenheim [192] demonstrated that cellular, proliferative responses to a crude, whole parasite antigen could be detected in donors up to 15 years following a single malaria infection. More recently, Todryk et al. [42] found undiminished IFN- $\gamma$ effector responses at 3 months postinfection in previously naïve volunteers, and data from our own laboratory suggest such IFN- $\gamma$ recall responses to whole pRBC remain practically undiminished at least 14 months postinfection (unpublished results). Thus, although responses to individual antigens or epitopes may be unstable, possibly representing in vivo fluctuations in individual $\mathrm{T}$ cell clones, the total IFN- $\gamma$ response to pRBC can remain remarkably longlived.

It comes somewhat of a surprise therefore to find that adult residents of highly endemic regions produce markedly lower IFN- $\gamma$ responses against $\mathrm{pRBC}$ than residents of low-endemic regions or indeed even nonexposed donors [194, 202] and that plasma IFN- $\gamma$ levels during clinical malaria episodes are relatively lower in semi-immune rather than in nonimmune patients $[118,119]$. Depressed responses in highly exposed individuals can be rescued by supplementation of exogenous
IL-2 [203]. Furthermore, these defective responses appear to be antigen-specific [194, 202], suggesting clonal elimination or specific suppression by regulatory T cells [204, 205]. In either case, down-regulation of proinflammatory responses has been proposed to be a beneficial adaptation by the host to avoid immunopathology as a result of repeated or chronic malaria infections [206], although as we have seen that there is limited evidence to support this hypothesis with regard to IFN- $\gamma$ in humans.

\section{Modulation of IFN- $\boldsymbol{\gamma}$ responses by the parasite}

Various mechanisms by which malaria parasites may actively suppress cellular immune responses have been reviewed elsewhere [206, 207]. Suppression of (protective) proinflammatory responses may be an active strategy pursued by malaria parasites to prolong their own survival in the host. Indeed, suppression of proliferation (e.g., refs. [208, 209]) and IFN- $\gamma$ production [193, 210] during clinical malaria episodes is a common, although not universal [211], finding. Evidence that repeated or chronic parasitemia also suppress IFN- $\gamma$ responses has arisen from longitudinal field studies [59] and long-term chemoprophylaxis studies [212]. Thus, it appears that downregulation of cellular responses in general and IFN- $\gamma$, in particular, is not only an active strategy pursued by the parasite but also that this strategy is so central to its survival that it has evolved multiple mechanisms by which to achieve it.

\section{IMPLICATIONS FOR VACCINE DEVELOPMENT}

Given this evidence for the protective effect of IFN- $\gamma$ against parasitemia, developing a malaria vaccine aimed at reproduc- 
ing such IFN- $\gamma$ responses would appear to be desirable. Whether "the stronger, the better" in terms of IFN- $\gamma$ responses should be the ultimate goal of malaria vaccine development must eventually depend on a more precise understanding of the complex relationship between IFN- $\gamma$ and manifestions of severe disease. Nevertheless, in designing any such vaccine strategy, a number of lessons can be drawn from what we understand currently about the factors that determine the magnitude of IFN- $\gamma$ responses against malaria.

\section{Induce multiple cellular pathways and a broad IFN- $\gamma$ response}

In addition to traditional $\alpha \beta$ T cells, NK cells and $\gamma \delta \mathrm{T}$ cells form important tappable sources of IFN- $\gamma$. Their IFN- $\gamma$ response against malaria parasites is induced through distinct pathways that can be exploited in vaccine design, i.e., by the inclusion of phosphoantigens to activate $\gamma \delta \mathrm{T}$, or whole parasites to activate IFN- $\gamma$ production by NK cells (see Cellular sources of IFN- $\gamma$ against different parasite life stages above). Although generally considered "innate" lymphocytes, we (unpublished results) and others [213, 214] have clearly demonstrated "memory-like" patterns in the IFN- $\gamma$ responses of these cells, supporting their rational inclusion in vaccine design. Exploiting such alternative cellular pathways furthermore bypasses parasite-mediated inhibition of IFN- $\gamma$ responses in $\alpha \beta$ T cells.

The problem of short-lived or IFN- $\gamma$ erratic responses to individual antigens can be overcome partially by inducing a broader response, e.g., by whole parasite-based vaccines. These expose the host's immune system to the full palette of parasite antigens, ideally also inducing IFN- $\gamma$ against multiple life stages. Furthermore, whole parasites contain a "built-in adjuvant", augmenting overall IFN- $\gamma$ responses further [183]. Indeed whole parasite-based vaccine approaches induce robust IFN- $\gamma$ responses in humans $[19,20,53]$ and have generally proven more successful than subunit vaccines [215-218].

\section{Prevent exposure-mediated suppression of IFN- $\gamma$ responses}

As suppression of IFN- $\gamma$ responses in relation to exposure does not seem to serve the host but rather appears solely a survival strategy by the parasite, the question arises whether/how such suppression can be avoided in the context of vaccine-induced IFN- $\gamma$ responses. In other words, does suppression of IFN- $\gamma$ responses automatically follow from repeated exposure, and can we design strategies to bypass it? Further field studies addressing the mechanism(s) underlying immune suppression in relation to exposure will be necessary but are complicated by the fact that in endemic settings, the effect of exposure cannot be distinguished readily from the effect of age [219]. Infants' and children's immune systems function differently from adults', quantitatively and qualitatively (e.g., refs. [220, 221]), and it could be hypothesized that the basis for life-long, suppressed IFN- $\gamma$ responses against malaria is laid in the immature immune systems of infants in highly endemic areas [222]. However, only little is understood about the effect of age on (cellular) immune responses to malaria from rodent models
[223-225], and although IFN- $\gamma$ responses against malaria in human children growing up in endemic areas tend to be weaker than in adults [61, 68, 226-228], the effect of prior exposure in these studies is again hard to distinguish from that of age per se.

One potential approach to answering these related questions would be to study IFN- $\gamma$ responses in people who become highly exposed to malaria only later in childhood or in adulthood, e.g., transmigrants, as has been performed for humoral responses in Javanese transmigrants to Irian Jaya [229231] or in settings of epidemic or resurgent malaria such as Madagascar [232].

\section{CONCLUDING REMARKS}

In this review, we have shown how IFN- $\gamma$ forms a critical component of immune responses against pre-erythrocytic and blood-stage malaria parasites. A wealth of evidence supports its protective efficacy against clinical malaria episodes, whereas the evidence associating IFN- $\gamma$ responses with immunopathology remains equivocal and will require further investigation. In the meantime, striving for strong and long-lasting IFN- $\gamma$ production appears justified as a malaria vaccine strategy, and to achieve this, such vaccines should be designed to induce a broad response via multiple cellular pathways. Additionally, the mechanism by which repeated exposure leads to suppression of such responses needs to be resolved.

\section{AUTHORSHIP}

M.B.B.M and R.W.S. wrote the paper.

\section{ACKNOWLEDGMENTS}

M.B.B.M. was supported by a European Union FP6 Network of Excellence (BioMalPar) fellowship.

\section{REFERENCES}

1. Schroder, K., Hertzog, P. J., Ravasi, T., Hume, D. A. (2004) Interferon- $\gamma$ : an overview of signals, mechanisms and functions. J. Leukoc. Biol. 75, 163-189.

2. Gessani, S., Belardelli, F. (1998) IFN- $\gamma$ expression in macrophages and its possible biological significance. Cytokine Growth Factor Rev. 9, 117-123.

3. Frucht, D. M., Fukao, T., Bogdan, C., Schindler, H., O'Shea, J. J., Koyasu, S. (2001) IFN- $\gamma$ production by antigen-presenting cells: mechanisms emerge. Trends Immunol. 22, 556-560.

4. Munder, M., Mallo, M., Eichmann, K., Modolell, M. (1998) Murine macrophages secrete interferon $\gamma$ upon combined stimulation with interleukin (IL)-12 and IL-18: a novel pathway of autocrine macrophage activation. J. Exp. Med. 187, 2103-2108.

5. Otani, T., Nakamura, S., Toki, M., Motoda, R., Kurimoto, M., Orita, K. (1999) Identification of IFN- $\gamma$-producing cells in IL-12/IL-18-treated mice. Cell. Immunol. 198, 111-119.

6. Buchmeier, N. A., Schreiber, R. D. (1985) Requirement of endogenous interferon- $\gamma$ production for resolution of Listeria monocytogenes infection. Proc. Natl. Acad. Sci. USA 82, 7404-7408.

7. Huang, S., Hendriks, W., Althage, A., Hemmi, S., Bluethmann, H., Kamijo, R., Vilcek, J., Zinkernagel, R. M., Aguet, M. (1993) Immune response in mice that lack the interferon- $\gamma$ receptor. Science 259, 17421745 .

8. Van den Broek, M. F., Muller, U., Huang, S., Zinkernagel, R. M., Aguet, M. (1995) Immune defense in mice lacking type I and/or type II interferon receptors. Immunol. Rev. 148, 5-18.

9. Murray, H. W., Rubin, B. Y., Rothermel, C. D. (1983) Killing of intracellular Leishmania donovani by lymphokine-stimulated human mononu- 
clear phagocytes. Evidence that interferon- $\gamma$ is the activating lymphokine. J. Clin. Invest. 72, 1506-1510.

10. Torrico, F., Heremans, H., Rivera, M. T., Van, M. E., Billiau, A., Carlier, Y. (1991) Endogenous IFN- $\gamma$ is required for resistance to acute Trypanosoma cruzi infection in mice. J. Immunol. 146, 3626-3632.

11. Scharton-Kersten, T. M., Wynn, T. A., Denkers, E. Y., Bala, S., Grunvald, E., Hieny, S., Gazzinelli, R. T., Sher, A. (1996) In the absence of endogenous IFN- $\gamma$, mice develop unimpaired IL-12 responses to Toxoplasma gondii while failing to control acute infection. J. Immunol. 157, 40454054 .

12. Miller, L. H., Howard, R. J., Carter, R., Good, M. F., Nussenzweig, V., Nussenzweig, R. S. (1986) Research toward malaria vaccines. Science 234, $1349-1356$.

13. Kuvin, S. F., Tobie, J. E., Evans, C. B., Coatney, G. R., Contacos, P. G. (1962) Antibody production in human malaria as determined by the fluorescent antibody technique. Science 135, 1130-1131.

14. Clyde, D. F., McCarthy, V. C., Miller, R. M., Hornick, R. B. (1973) Specificity of protection of man immunized against sporozoite-induced falciparum malaria. Am. J. Med. Sci. 266, 398-403.

15. Doolan, D. L., Martinez-Alier, N. (2006) Immune response to preerythrocytic stages of malaria parasites. Curr. Mol. Med. 6, 169-185.

16. Perrin, L. H., Dayal, R. (1982) Immunity to asexual erythrocytic stages of Plasmodium falciparum: role of defined antigens in the humoral response. Immunol. Rev. 61, 245-269.

17. Yazdani, S. S., Mukherjee, P., Chauhan, V. S., Chitnis, C. E. (2006) Immune responses to asexual blood-stages of malaria parasites. Curr. Mol. Med. 6, 187-203.

18. Beeson, J. G., Osier, F. H., Engwerda, C. R. (2008) Recent insights into humoral and cellular immune responses against malaria. Trends Parasitol. 24, 578-584.

19. Pombo, D. J., Lawrence, G., Hirunpetcharat, C., Rzepczyk, C., Bryden, M., Cloonan, N., Anderson, K., Mahakunkijcharoen, Y., Martin, L. B., Wilson, D., Elliott, S., Elliott, S., Eisen, D. P., Weinberg, J. B., Saul, A., Good, M. F. (2002) Immunity to malaria after administration of ultralow doses of red cells infected with Plasmodium falciparum. Lancet 360, $610-617$.

20. Roestenberg, M., McCall, M., Hopman, J., Wiersma, J., Luty, A. J., van Gemert, G. J., van de Vegte-Bolmer, M., van Schaijk, B., Teelen, K. Arens, T., Spaarman, L., de Mast, Q., Roeffen, W., Snounou, G., Rénia, L., van der Ven, A., Hermsen, C. C., Sauerwein, R. (2009) Protection against a malaria challenge by sporozoite inoculation. N. Engl. J. Med. 361, 468-477.

21. Kumaratilake, L. M., Ferrante, A. (1994) T-cell cytokines in malaria: their role in the regulation of neutrophil- and macrophage-mediated killing of Plasmodium falciparum asexual blood forms. Res. Immunol. 145, 423-429.

22. Bouharoun-Tayoun, H., Oeuvray, C., Lunel, F., Druilhe, P. (1995) Mechanisms underlying the monocyte-mediated antibody-dependent killing of Plasmodium falciparum asexual blood stages. J. Exp. Med. 182, 409-418.

23. Nussler, A. K., Renia, L., Pasquetto, V., Miltgen, F., Matile, H., Mazier, D. (1993) In vivo induction of the nitric oxide pathway in hepatocytes after injection with irradiated malaria sporozoites, malaria blood parasites or adjuvants. Eur. J. Immunol. 23, 882-887.

24. Seguin, M. C., Klotz, F. W., Schneider, I., Weir, J. P., Goodbary, M., Slayter, M., Raney, J. J., Aniagolu, J. U., Green, S. J. (1994) Induction of nitric oxide synthase protects against malaria in mice exposed to irradiated Plasmodium berghei infected mosquitoes: involvement of interferon $\gamma$ and CD8+ T cells. J. Exp. Med. 180, 353-358.

25. Tsuji, M., Miyahira, Y., Nussenzweig, R. S., Aguet, M., Reichel, M., Zavala, F. (1995) Development of antimalaria immunity in mice lacking IFN- $\gamma$ receptor. J. Immunol. 154, 5338-5344.

26. Ockenhouse, C. F., Schulman, S., Shear, H. L. (1984) Induction of crisis forms in the human malaria parasite Plasmodium falciparum by $\gamma$-interferon-activated, monocyte-derived macrophages. J. Immunol. 133, 16011608.

27. Shear, H. L., Srinivasan, R., Nolan, T., Ng, C. (1989) Role of IFN- $\gamma$ in lethal and nonlethal malaria in susceptible and resistant murine hosts. J. Immunol. 143, 2038-2044.

28. Su, Z., Stevenson, M. M. (2000) Central role of endogenous $\gamma$ interferon in protective immunity against blood-stage Plasmodium chabaudi AS infection. Infect. Immun. 68, 4399-4406.

29. Wang, Q. H., Liu, Y. J., Liu, J., Chen, G., Zheng, W., Wang, J. C., Cao, Y. M. (2009) Plasmodium yoelii: assessment of production and role of nitric oxide during the early stages of infection in susceptible and resistant mice. Exp. Parasitol. 121, 268-273.

30. Kumaratilake, L. M., Ferrante, A. (2000) Opsonization and phagocytosis of Plasmodium falciparum merozoites measured by flow cytometry. Clin. Diagn. Lab. Immunol. 7, 9-13.

31. Yoneto, T., Waki, S., Takai, T., Tagawa, Y., Iwakura, Y., Mizuguchi, J., Nariuchi, H., Yoshimoto, T. (2001) A critical role of Fc receptor-mediated antibody-dependent phagocytosis in the host resistance to bloodstage Plasmodium berghei XAT infection. J. Immunol. 166, 6236-6241.
32. Su, Z., Fortin, A., Gros, P., Stevenson, M. M. (2002) Opsonin-independent phagocytosis: an effector mechanism against acute blood-stage Plasmodium chabaudi AS infection. J. Infect. Dis. 186, 1321-1329.

33. Naotunne, T. S., Karunaweera, N. D., Del, G. G., Kularatne, M. U., Grau, G. E., Carter, R., Mendis, K. N. (1991) Cytokines kill malaria parasites during infection crisis: extracellular complementary factors are essential. J. Exp. Med. 173, 523-529.

34. McCall, M. B., Netea, M. G., Hermsen, C. C., Jansen, T., Jacobs, L., Golenbock, D., van der Ven, A. J., Sauerwein, R. W. (2007) Plasmodium falciparum infection causes proinflammatory priming of human TLR responses. J. Immunol. 179, 162-171.

35. Adegnika, A. A., Kohler, C., Agnandji, S. T., Chai, S. K., Labuda, L., Breitling, L. P., Schonkeren, D., Weerdenburg, E., Issifou, S., Luty, A. J., Kremsner, P. G., Yazdanbakhsh, M. (2008) Pregnancy-associated malaria affects Toll-like receptor ligand-induced cytokine responses in cord blood. J. Infect. Dis. 198, 928-936.

36. Hartgers, F. C., Obeng, B. B., Voskamp, A., Larbi, I. A., Amoah, A. S., Luty, A. J., Boakye, D., Yazdanbakhsh, M. (2008) Enhanced Toll-like receptor responsiveness associated with mitogen-activated protein kinase activation in Plasmodium falciparum-infected children. Infect. Immun. 76 , $5149-5157$.

37. Franklin, B. S., Parroche, P., Ataide, M. A., Lauw, F., Ropert, C., de Oliveira, R. B., Pereira, D., Tada, M. S., Nogueira, P., da Silva, L. H., Bjorkbacka, H., Golenbock, D. T., Gazzinelli, R. T. (2009) Malaria primes the innate immune response due to interferon- $\gamma$ induced enhancement of Toll-like receptor expression and function. Proc. Natl. Acad. Sci. USA 106, 5789-5794.

38. Brustoski, K., Moller, U., Kramer, M., Petelski, A., Brenner, S., Palmer, D. R., Bongartz, M., Kremsner, P. G., Luty, A. J., Krzych, U. (2005) IFN- $\gamma$ and IL-10 mediate parasite-specific immune responses of cord blood cells induced by pregnancy-associated Plasmodium falciparum malaria. J. Immunol. 174, 1738-1745.

39. Winkler, S., Willheim, M., Baier, K., Schmid, D., Aichelburg, A., Graninger, W., Kremsner, P. G. (1998) Reciprocal regulation of Th1and Th2-cytokine-producing $\mathrm{T}$ cells during clearance of parasitemia in Plasmodium falciparum malaria. Infect. Immun. 66, 6040-6044.

40. Tongren, J. E., Corran, P. H., Jarra, W., Langhorne, J., Riley, E. M. (2005) Epitope-specific regulation of immunoglobulin class switching in mice immunized with malarial merozoite surface proteins. Infect. Immun. 73, 8119-8129.

41. Bejon, P., Keating, S., Mwacharo, J., Kai, O. K., Dunachie, S., Walther, M., Berthoud, T., Lang, T., Epstein, J., Carucci, D., Moris, P., Cohen, J., Gilbert, S. C., Peshu, N., Marsh, K., Hill, A. V. (2006) Early $\gamma$ interferon and interleukin-2 responses to vaccination predict the late resting memory in malaria-naive and malaria-exposed individuals. Infect. Immun. 74, 6331-6338.

42. Todryk, S. M., Walther, M., Bejon, P., Hutchings, C., Thompson, F. M., Urban, B. C., Porter, D. W., Hill, A. V. (2009) Multiple functions of human $\mathrm{T}$ cells generated by experimental malaria challenge. Eur. J. Immunol. 39, 3042-3051.

43. Schofield, L., Villaquiran, J., Ferreira, A., Schellekens, H., Nussenzweig, R., Nussenzweig, V. (1987) $\gamma$ Interferon, CD8 + T cells and antibodies required for immunity to malaria sporozoites. Nature 330, 664-666.

44. Hoffman, S. L., Isenbarger, D., Long, G. W., Sedegah, M., Szarfman, A. Waters, L., Hollingdale, M. R., van der Meide, P. H., Finbloom, D. S., Ballou, W. R. (1989) Sporozoite vaccine induces genetically restricted T cell elimination of malaria from hepatocytes. Science 244, 1078-1081.

45. Doolan, D. L., Sedegah, M., Hedstrom, R. C., Hobart, P., Charoenvit, Y., Hoffman, S. L. (1996) Circumventing genetic restriction of protection against malaria with multigene DNA immunization: CD8 + cell-, interferon $\gamma$-, and nitric oxide-dependent immunity. J. Exp. Med. 183, 17391746.

46. Wang, R., Charoenvit, Y., Corradin, G., De La Vega, P., Franke, E. D., Hoffman, S. L. (1996) Protection against malaria by Plasmodium yoelii sporozoite surface protein 2 linear peptide induction of CD4+ T celland IFN- $\gamma$-dependent elimination of infected hepatocytes. J. Immunol. 157, 4061-4067.

47. Doolan, D. L., Hoffman, S. L. (1999) IL-12 and NK cells are required for antigen-specific adaptive immunity against malaria initiated by CD8+ T cells in the Plasmodium yoelii model. J. Immunol. 163, 884-892.

48. Belnoue, E., Voza, T., Costa, F. T., Gruner, A. C., Mauduit, M., Rosa, D. S., Depinay, N., Kayibanda, M., Vigario, A. M., Mazier, D., Snounou, G., Sinnis, P., Renia, L. (2008) Vaccination with live Plasmodium yoelii blood stage parasites under chloroquine cover induces cross-stage immunity against malaria liver stage. J. Immunol. 181, 8552-8558.

49. Ferreira, A., Schofield, L., Enea, V., Schellekens, H., van der Meide, P., Collins, W. E., Nussenzweig, R. S., Nussenzweig, V. (1986) Inhibition of development of exoerythrocytic forms of malaria parasites by $\gamma$-interferon. Science 232, 881-884.

50. Sedegah, M., Finkelman, F., Hoffman, S. L. (1994) Interleukin 12 induction of interferon $\gamma$-dependent protection against malaria. Proc. Natl. Acad. Sci. USA 91, 10700-10702.

51. Hoffman, S. L., Crutcher, J. M., Puri, S. K., Ansari, A. A., Villinger, F., Franke, E. D., Singh, P. P., Finkelman, F., Gately, M. K., Dutta, G. P., 
Sedegah, M. (1997) Sterile protection of monkeys against malaria after administration of interleukin-12. Nat. Med. 3, 80-83.

52. Walther, M., Woodruff, J., Edele, F., Jeffries, D., Tongren, J. E., King, E., Andrews, L., Bejon, P., Gilbert, S. C., De Souza, J. B., Sinden, R., Hill, A. V., Riley, E. M. (2006) Innate immune responses to human malaria: heterogeneous cytokine responses to blood-stage Plasmodium falciparum correlate with parasitological and clinical outcomes. J. Immunol. 177, $5736-5745$.

53. Hoffman, S. L., Goh, L. M., Luke, T. C., Schneider, I., Le, T. P., Doolan, D. L., Sacci, J., de la Vega, P., Dowler, M., Paul, C., Gordon, D. M., Stoute, J. A., Church, L. W., Sedegah, M., Heppner, D. G., Ballou, W. R., Richie, T. L. (2002) Protection of humans against malaria by immunization with radiation-attenuated Plasmodium falciparum sporozoites. J. Infect. Dis. 185, 1155-1164.

54. Egan, J. E., Hoffman, S. L., Haynes, J. D., Sadoff, J. C., Schneider, I., Grau, G. E., Hollingdale, M. R., Ballou, W. R., Gordon, D. M. (1993) Humoral immune responses in volunteers immunized with irradiated Plasmodium falciparum sporozoites. Am. J. Trop. Med. Hyg. 49, 166-173.

55. Malik, A., Egan, J. E., Houghten, R. A., Sadoff, J. C., Hoffman, S. L (1991) Human cytotoxic T lymphocytes against the Plasmodium falciparum circumsporozoite protein. Proc. Natl. Acad. Sci. USA 88, 3300-3304.

56. Moreno, A., Clavijo, P., Edelman, R., Davis, J., Sztein, M., Herrington, D., Nardin, E. (1991) Cytotoxic CD4+ T cells from a sporozoite-immunized volunteer recognize the Plasmodium falciparum $\mathrm{CS}$ protein. Int. Immunol. 3, 997-1003.

57. Nardin, E. H., Herrington, D. A., Davis, J., Levine, M., Stuber, D. Takacs, B., Caspers, P., Barr, P., Altszuler, R., Clavijo, P. (1989) Conserved repetitive epitope recognized by $\mathrm{CD} 4+$ clones from a malariaimmunized volunteer. Science 246, 1603-1606.

58. Doolan, D. L., Southwood, S., Chesnut, R., Appella, E., Gomez, E., Richards, A., Higashimoto, Y. I., Maewal, A., Sidney, J., Gramzinski, R. A., Mason, C., Koech, D., Hoffman, S. L., Sette, A. (2000) HLA-DR-promiscuous T cell epitopes from Plasmodium falciparum pre-erythrocytic-stage antigens restricted by multiple HLA class II alleles. J. Immunol. 165, $1123-1137$.

59. Bejon, P., Mwacharo, J., Kai, O., Todryk, S., Keating, S., Lowe, B., Lang, T., Mwangi, T. W., Gilbert, S. C., Peshu, N., Marsh, K., Hill, A. V. (2007) The induction and persistence of T cell IFN- $\gamma$ responses after vaccination or natural exposure is suppressed by Plasmodium falciparum. J. Immunol. 179, 4193-4201.

60. Dent, A. E., Chelimo, K., Sumba, P. O., Spring, M. D., Crabb, B. S., Moormann, A. M., Tisch, D. J., Kazura, J. W. (2009) Temporal stability of naturally acquired immunity to merozoite surface protein- 1 in Kenyan adults. Malar. J. 8, 162.

61. Moormann, A. M., Sumba, P. O., Tisch, D. J., Embury, P., King, C. H. Kazura, J. W., John, C. C. (2009) Stability of interferon- $\gamma$ and interleukin-10 responses to Plasmodium falciparum liver stage antigen 1 and thrombospondin-related adhesive protein immunodominant epitopes in a highland population from Western Kenya. Am. J. Trop. Med. Hyg. 81, $489-495$.

62. Deloron, P., Chougnet, C., Lepers, J. P., Tallet, S., Coulanges, P. (1991) Protective value of elevated levels of $\gamma$ interferon in serum against exoerythrocytic stages of Plasmodium falciparum. J. Clin. Microbiol. 29, 17571760 .

63. Riley, E. M., Allen, S. J., Bennett, S., Thomas, P. J., O'Donnell, A., Lindsay, S. W., Good, M. F., Greenwood, B. M. (1990) Recognition of dominant $\mathrm{T}$ cell-stimulating epitopes from the circumsporozoite protein of Plasmodium falciparum and relationship to malaria morbidity in Gambian children. Trans. R. Soc. Trop. Med. Hyg. 84, 648-657.

64. Kurtis, J. D., Lanar, D. E., Opollo, M., Duffy, P. E. (1999) Interleukin-10 responses to liver-stage antigen 1 predict human resistance to Plasmodium falciparum. Infect. Immun. 67, 3424-3429.

65. Migot-Nabias, F., Deloron, P., Ringwald, P., Dubois, B., Mayombo, J., Minh, T. N., Fievet, N., Millet, P., Luty, A. (2000) Immune response to Plasmodium falciparum liver stage antigen-1: geographical variations within Central Africa and their relationship with protection from clinical malaria. Trans. R. Soc. Trop. Med. Hyg. 94, 557-562.

66. Luty, A. J., Lell, B., Schmidt-Ott, R., Lehman, L. G., Luckner, D., Greve, B., Matousek, P., Herbich, K., Schmid, D., Migot-Nabias, F., Deloron, P., Nussenzweig, R. S., Kremsner, P. G. (1999) Interferon- $\gamma$ responses are associated with resistance to reinfection with Plasmodium falciparum in young African children. J. Infect. Dis. 179, 980-988.

67. May, J., Lell, B., Luty, A. J., Meyer, C. G., Kremsner, P. G. (2001) HLADQB1*0501-restricted Th1 type immune responses to Plasmodium falciparum liver stage antigen 1 protect against malaria anemia and reinfections. J. Infect. Dis. 183, 168-172.

68. John, C. C., Moormann, A. M., Sumba, P. O., Ofulla, A. V., Pregibon, D. C., Kazura, J. W. (2004) $\gamma$ Interferon responses to Plasmodium falciparum liver-stage antigen 1 and thrombospondin-related adhesive protein and their relationship to age, transmission intensity, and protection against malaria. Infect. Immun. 72, 5135-5142.

69. Reece, W. H., Pinder, M., Gothard, P. K., Milligan, P., Bojang, K., Doherty, T., Plebanski, M., Akinwunmi, P., Everaere, S., Watkins, K. R., Voss, G., Tornieporth, N., Alloueche, A., Greenwood, B. M., Kester, K. E., McAdam, K. P., Cohen, J., Hill, A. V. (2004) A CD4(+) T-cell im- mune response to a conserved epitope in the circumsporozoite protein correlates with protection from natural Plasmodium falciparum infection and disease. Nat. Med. 10, 406-410.

70. Flanagan, K. L., Mwangi, T., Plebanski, M., Odhiambo, K., Ross, A., Sheu, E., Kortok, M., Lowe, B., Marsh, K., Hill, A. V. (2003) Ex vivo interferon- $\gamma$ immune response to thrombospondin-related adhesive protein in coastal Kenyans: longevity and risk of Plasmodium falciparum infection. Am. J. Trop. Med. Hyg. 68, 421-430.

71. Todryk, S. M., Bejon, P., Mwangi, T., Plebanski, M., Urban, B., Marsh, K., Hill, A. V., Flanagan, K. L. (2008) Correlation of memory T cell responses against TRAP with protection from clinical malaria, and CD4 CD25 high T cells with susceptibility in Kenyans. PLoS One 3, e2027.

72. Vekemans, J., Leach, A., Cohen, J. (2009) Development of the RTS,S/AS malaria candidate vaccine. Vaccine 27 (Suppl. 6), G67-G71.

73. Sun, P., Schwenk, R., White, K., Stoute, J. A., Cohen, J., Ballou, W. R., Voss, G., Kester, K. E., Heppner, D. G., Krzych, U. (2003) Protective immunity induced with malaria vaccine, RTS,S, is linked to Plasmodium falciparum circumsporozoite protein-specific $\mathrm{CD} 4+$ and $\mathrm{CD} 8+\mathrm{T}$ cells producing IFN- $\gamma$. J. Immunol. 171, 6961-6967.

74. Kester, K. E., Cummings, J. F., Ockenhouse, C. F., Nielsen, R., Hall, B. T., Gordon, D. M., Schwenk, R. J., Krzych, U., Holland, C. A., Richmond, G., Dowler, M. G., Williams, J., Wirtz, R. A., Tornieporth, N., Vigneron, L., Delchambre, M., Demoitie, M. A., Ballou, W. R., Cohen, J., Heppner Jr., D. G. (2008) Phase 2a trial of 0,1 , and 3 month and 0 , 7 , and 28 dav immunization schedules of malaria vaccine RTS,S/AS02 in malaria-naive adults at the Walter Reed Army Institute of Research. Vaccine 26, 2191-2202.

75. Kester, K. E., Cummings, J. F., Ofori-Anyinam, O., Ockenhouse, C. F., Krzych, U., Moris, P., Schwenk, R., Nielsen, R. A., Debebe, Z., Pinelis, E., Juompan, L., Williams, J., Dowler, M., Stewart, V. A., Wirtz, R. A., Dubois, M. C., Lievens, M., Cohen, J., Ballou, W. R., Heppner Jr., D. G. (2009) Randomized, double-blind, phase 2a trial of falciparum malaria vaccines RTS,S/AS01B and RTS,S/AS02A in malaria-naive adults: safety, efficacy, and immunologic associates of protection. J. Infect. Dis. 200, $337-346$.

76. Barbosa, A., Naniche, D., Aponte, J. J., Manaca, M. N., Mandomando, I., Aide, P., Sacarlal, J., Renom, M., Lafuente, S., Ballou, W. R., Alonso, P. L. (2009) Plasmodium falciparum-specific cellular immune responses after immunization with the RTS,S/AS02D candidate malaria vaccine in infants living in an area of high endemicity in Mozambique. Infect. Immun. 77, 4502-4509.

77. Cummings, J. F., Spring, M. D., Schwenk, R. J., Ockenhouse, C. F., Kester, K. E., Polhemus, M. E., Walsh, D. S., Yoon, I. K., Prosperi, C., Juompan, L. Y., Lanar, D. E., Krzych, U., Hall, B. T., Ware, L. A., Stewart, V. A., Williams, J., Dowler, M., Nielsen, R. K., Hillier, C. J., Giersing, B. K., Dubovsky, F., Malkin, E., Tucker, K., Dubois, M. C., Cohen, J. D., Ballou, D. R., Heppner, D. G. Jr. (2009) Recombinant liver stage antigen-1 (LSA-1) formulated with AS01 or AS02 is safe, elicits high titer antibody and induces IFN- $\gamma / \mathrm{IL}-2$ CD $4+\mathrm{T}$ cells but does not protect against experimental Plasmodium falciparum infection. Vaccine, Epub ahead of print.

78. Keating, S. M., Bejon, P., Berthoud, T., Vuola, J. M., Todryk, S., Webster, D. P., Dunachie, S. J., Moorthy, V. S., McConkey, S. J., Gilbert, S. C., Hill, A. V. (2005) Durable human memory T cells quantifiable by cultured enzyme-linked immunospot assays are induced by heterologous prime boost immunization and correlate with protection against malaria. J. Immunol. 175, 5675-5680.

79. Webster, D. P., Dunachie, S., Vuola, J. M., Berthoud, T., Keating, S., Laidlaw, S. M., McConkey, S. J., Poulton, I., Andrews, L., Andersen, R. F., Bejon, P., Butcher, G., Sinden, R., Skinner, M. A., Gilbert, S. C., Hill, A. V. (2005) Enhanced T cell-mediated protection against malaria in human challenges by using the recombinant poxviruses FP9 and modified vaccinia virus Ankara. Proc. Natl. Acad. Sci. USA 102, $4836-$ 4841.

80. Good, M. F., Xu, H., Wykes, M., Engwerda, C. R. (2005) Development and regulation of cell-mediated immune responses to the blood stages of malaria: implications for vaccine research. Annu. Rev. Immunol. 23, $69-99$.

81. Urban, B. C., Ing, R., Stevenson, M. M. (2005) Early interactions between blood-stage Plasmodium parasites and the immune system. Curr. Top. Microbiol. Immunol. 297, 25-70.

82. van der Heyde, H. C., Pepper, B., Batchelder, J., Cigel, F., Weidanz, W. P. (1997) The time course of selected malarial infections in cytokinedeficient mice. Exp. Parasitol. 85, 206-213.

83. Amani, V., Vigario, A. M., Belnoue, E., Marussig, M., Fonseca, L. Mazier, D., Renia, L. (2000) Involvement of IFN- $\gamma$ receptor-medicated signaling in pathology and anti-malarial immunity induced by Plasmodium berghei infection. Eur. J. Immunol. 30, 1646-1655.

84. Favre, N., Ryffel, B., Bordmann, G., Rudin, W. (1997) The course of Plasmodium chabaudi chabaudi infections in interferon- $\gamma$ receptor deficient mice. Parasite Immunol. 19, 375-383.

85. Meding, S. J., Cheng, S. C., Simon-Haarhaus, B., Langhorne, J. (1990) Role of $\gamma$ interferon during infection with Plasmodium chabaudi chabaudi. Infect. Immun. 58, 3671-3678. 
86. Stevenson, M. M., Tam, M. F., Belosevic, M., van der Meide, P. H., Podoba, J. E. (1990) Role of endogenous $\gamma$ interferon in host response to infection with blood-stage Plasmodium chabaudi AS. Infect. Immun. 58, 3225-3232.

87. Yoneto, T., Yoshimoto, T., Wang, C. R., Takahama, Y., Tsuji, M., Waki, S., Nariuchi, H. (1999) $\gamma$ Interferon production is critical for protective immunity to infection with blood-stage Plasmodium berghei XAT but neither NO production nor NK cell activation is critical. Infect. Immun. 67 , $2349-2356$.

88. Edstein, M. D., Kotecka, B. M., Anderson, K. L., Pombo, D. J., Kyle, D. E., Rieckmann, K. H., Good, M. F. (2005) Lengthy antimalarial activity of atovaquone in human plasma following atovaquone-proguanil administration. Antimicrob. Agents Chemother. 49, 4421-4422.

89. Ramharter, M., Kremsner, P. G., Willheim, M., Winkler, H., Graninger, W., Winkler, S. (2004) Plasmodium falciparum-specific interleukin-2 and tumor necrosis factor- $\alpha$ expressing-T cells are associated with resistance to reinfection and severe malaria in healthy African children. Eur. Cytokine Netw. 15, 189-196.

90. Dodoo, D., Omer, F. M., Todd, J., Akanmori, B. D., Koram, K. A., Riley, E. M. (2002) Absolute levels and ratios of proinflammatory and antiinflammatory cytokine production in vitro predict clinical immunity to Plasmodium falciparum malaria. J. Infect. Dis. 185, 971-979.

91. D'Ombrain, M. C., Robinson, L. J., Stanisic, D. I., Taraika, J., Bernard, N., Michon, P., Mueller, I., Schofield, L. (2008) Association of early interferon- $\gamma$ production with immunity to clinical malaria: a longitudinal study among Papua New Guinean children. Clin. Infect. Dis. 47, 13801387.

92. Robinson, L. J., D'Ombrain, M. C., Stanisic, D. I., Taraika, J., Bernard, N., Richards, J. S., Beeson, J. G., Tavul, L., Michon, P., Mueller, I., Schofield, L. (2009) Cellular tumor necrosis factor, $\gamma$ interferon, and interleukin-6 responses as correlates of immunity and risk of clinical Plasmodium falciparum malaria in children from Papua New Guinea. Infect. Immun. 77, 3033-3043.

93. McCall, M. B., Hopman, J., Daou, M., Maiga, B., Dara, V., Ploemen, I., Nganou-Makamdop, K., Niangaly, A., Tolo, Y., Arama, C., Bousema, J. T., van der Meer, J. W., van der Ven, A. J., Troye-Blomberg, M., Dolo, A., Doumbo, O. K., Sauerwein, R. W. (2010) Early interferon- $\gamma$ response against Plasmodium falciparum correlates with interethnic differences in susceptibility to parasitemia between sympatric Fulani and Dogon in Mali. J. Infect. Dis. 201, 142-152.

94. Riley, E. M., Allen, S. J., Troye-Blomberg, M., Bennett, S., Perlmann, H., Andersson, G., Smedman, L., Perlmann, P., Greenwood, B. M. (1991) Association between immune recognition of the malaria vaccine candidate antigen Pf155/RESA and resistance to clinical disease: a prospective study in a malaria-endemic region of West Africa. Trans. $R$. Soc. Trop. Med. Hyg. 85, 436-443.

95. Riley, E. M., Jakobsen, P. H., Allen, S. J., Wheeler, J. G., Bennett, S. Jepsen, S., Greenwood, B. M. (1991) Immune response to soluble exoantigens of Plasmodium falciparum may contribute to both pathogenesis and protection in clinical malaria: evidence from a longitudinal, prospective study of semi-immune African children. Eur. J. Immunol. 21, 1019-1025.

96. Al-Yaman, F., Genton, B., Taraika, J., Anders, R., Alpers, M. P. (1997) Association between cellular response (IL-4) to RESA/Pf155 and protection from clinical malaria among Papua New Guinean children living in a malaria endemic area. Parasite Immunol. 19, 249-254.

97. al-Yaman, F., Genton, B., Taraika, J., Anders, R., Alpers, M. P. (1997) Cellular immunity to merozoite surface protein 2 (FC27 and 3D7) in Papua New Guinean children. Temporal variation and relation to clinical and parasitological status. Parasite Immunol. 19, 207-214.

98. Luty, A. J., Lell, B., Schmidt-Ott, R., Lehman, L. G., Luckner, D., Greve, B., Matousek, P., Herbich, K., Schmid, D., Ulbert, S., Migot-Nabias, F., Dubois, B., Deloron, P., Kremsner, P. G. (1998) Parasite antigen-specific interleukin-10 and antibody reponses predict accelerated parasite clearance in Plasmodium falciparum malaria. Eur. Cytokine Netw. 9, 639-646.

99. Migot-Nabias, F., Luty, A. J., Ringwald, P., Vaillant, M., Dubois, B., Renaut, A., Mayombo, R. J., Minh, T. N., Fievet, N., Mbessi, J. R., Millet, P., Deloron, P. (1999) Immune responses against Plasmodium falciparum asexual blood-stage antigens and disease susceptibility in Gabonese and Cameroonian children. Am. J. Trop. Med. Hyg. 61, 488-494.

100. Riley, E. M., Allen, S. J., Wheeler, J. G., Blackman, M. J., Bennett, S., Takacs, B., Schonfeld, H. J., Holder, A. A., Greenwood, B. M. (1992) Naturally acquired cellular and humoral immune responses to the major merozoite surface antigen (PfMSP1) of Plasmodium falciparum are associated with reduced malaria morbidity. Parasite Immunol. 14, 321337.

101. Shaffer, N., Grau, G. E., Hedberg, K., Davachi, F., Lyamba, B., Hightower, A. W., Breman, J. G., Phuc, N. D. (1991) Tumor necrosis factor and severe malaria. I. Infect. Dis. 163, 96-101.

102. Jakobsen, P. H., McKay, V., Morris-Jones, S. D., McGuire, W., van Hensbroek, M. B., Meisner, S., Bendtzen, K., Schousboe, I., Bygbjerg, I. C., Greenwood, B. M. (1994) Increased concentrations of interleukin-6 and interleukin-1 receptor antagonist and decreased concentrations of $\beta$-2glycoprotein I in Gambian children with cerebral malaria. Infect. Immun. 62, $4374-4379$.
103. McGuire, W., Hill, A. V., Allsopp, C. E., Greenwood, B. M., Kwiatkowski, D. (1994) Variation in the TNF- $\alpha$ promoter region associated with susceptibility to cerebral malaria. Nature 371, 508-510.

104. Wenisch, C., Linnau, K. F., Looaresuwan, S., Rumpold, H. (1999) Plasma levels of the interleukin-6 cytokine family in persons with severe Plasmodium falciparum malaria. J. Infect. Dis. 179, 747-750.

105. Lyke, K. E., Burges, R., Cissoko, Y., Sangare, L., Dao, M., Diarra, I., Kone, A., Harley, R., Plowe, C. V., Doumbo, O. K., Sztein, M. B. (2004) Serum levels of the proinflammatory cytokines interleukin-1 $\beta$ (IL-1 $\beta$ ), IL-6, IL-8, IL-10, tumor necrosis factor $\alpha$, and IL-12(p70) in Malian children with severe Plasmodium falciparum malaria and matched uncomplicated malaria or healthy controls. Infect. Immun. 72, 5630-5637.

106. Grau, G. E., Heremans, H., Piguet, P. F., Pointaire, P., Lambert, P. H., Billiau, A., Vassalli, P. (1989) Monoclonal antibody against interferon $\gamma$ can prevent experimental cerebral malaria and its associated overproduction of tumor necrosis factor. Proc. Natl. Acad. Sci. USA 86, 55725574 .

107. De Kossodo, S., Grau, G. E. (1993) Profiles of cytokine production in relation with susceptibility to cerebral malaria. J. Immunol. 151, 48114820 .

108. Yanez, D. M., Manning, D. D., Cooley, A. J., Weidanz, W. P., van der Heyde, H. C. (1996) Participation of lymphocyte subpopulations in the pathogenesis of experimental murine cerebral malaria. J. Immunol. 157, $1620-1624$

109. Haque, A., Echchannaoui, H., Seguin, R., Schwartzman, J., Kasper, L. H., Haque, S. (2001) Cerebral malaria in mice: interleukin-2 treatment induces accumulation of $\gamma \delta \mathrm{T}$ cells in the brain and alters resistant mice to susceptible-like phenotype. Am. J. Pathol. 158, 163-172.

110. Curfs, J. H., van der Meide, P. H., Billiau, A., Meuwissen, J. H., Eling, W. M. (1993) Plasmodium berghei: recombinant interferon- $\gamma$ and the development of parasitemia and cerebral lesions in malaria-infected mice. Exp. Parasitol. 77, 212-223.

111. Singh, R. P., Kashiwamura, S., Rao, P., Okamura, H., Mukherjee, A. Chauhan, V. S. (2002) The role of IL-18 in blood-stage immunity against murine malaria Plasmodium yoelii 265 and Plasmodium berghei ANKA. J. Immunol. 168, 4674-4681.

112. Bullen, D. V., Hansen, D. S., Siomos, M. A., Schofield, L., Alexander, W. S., Handman, E. (2003) The lack of suppressor of cytokine signaling-1 (SOCS1) protects mice from the development of cerebral malaria caused by Plasmodium berghei ANKA. Parasite Immunol. 25, 113-118.

113. Hanum, P. S., Hayano, M., Kojima, S. (2003) Cytokine and chemokine responses in a cerebral malaria-susceptible or -resistant strain of mice to Plasmodium berghei ANKA infection: early chemokine expression in the brain. Int. Immunol. 15, 633-640.

114. Kremsner, P. G., Neifer, S., Chaves, M. F., Rudolph, R., Bienzle, U. (1992) Interferon- $\gamma$ induced lethality in the late phase of Plasmodium vinckei malaria despite effective parasite clearance by chloroquine. Eur. J. Immunol. 22, 2873-2878.

115. Yap, G. S., Stevenson, M. M. (1994) Inhibition of in vitro erythropoiesis by soluble mediators in Plasmodium chabaudi AS malaria: lack of a major role for interleukin 1, tumor necrosis factor $\alpha$, and $\gamma$ interferon. Infect. Immun. 62, 357-362.

116. Cross, C. E., Langhorne, J. (1998) Plasmodium chabaudi chabaudi (AS): inflammatory cytokines and pathology in an erythrocytic-stage infection in mice. Exp. Parasitol. 90, 220-229.

117. Harpaz, R., Edelman, R., Wasserman, S. S., Levine, M. M., Davis, J. R., Sztein, M. B. (1992) Serum cytokine profiles in experimental human malaria. Relationship to protection and disease course after challenge. J. Clin. Invest. 90, 515-523.

118. Ringwald, P., Peyron, F., Vuillez, J. P., Touze, J. E., Le Bras, J., Deloron, P. (1991) Levels of cytokines in plasma during Plasmodium falciparum malaria attacks. J. Clin. Microbiol. 29, 2076-2078.

119. Mshana, R. N., Boulandi, J., Mshana, N. M., Mayombo, J., Mendome, G (1991) Cytokines in the pathogenesis of malaria: levels of IL-I $\beta$, IL-4, IL-6, TNF- $\alpha$ and IFN- $\gamma$ in plasma of healthy individuals and malaria patients in a holoendemic area. J. Clin. Lab. Immunol. 34, 131-139.

120. Mordmuller, B. G., Metzger, W. G., Juillard, P., Brinkman, B. M., Verweij, C. L., Grau, G. E., Kremsner, P. G. (1997) Tumor necrosis factor in Plasmodium falciparum malaria: high plasma level is associated with fever, but high production capacity is associated with rapid fever clearance. Eur. Cytokine Netw. 8, 29-35.

121. Torre, D., Speranza, F., Giola, M., Matteelli, A., Tambini, R., Biondi, G. (2002) Role of Th1 and Th2 cytokines in immune response to uncomplicated Plasmodium falciparum malaria. Clin. Diagn. Lab. Immunol. 9, 348-351.

122. Ho, M., Sexton, M. M., Tongtawe, P., Looareesuwan, S., Suntharasamai, P., Webster, H. K. (1995) Interleukin-10 inhibits tumor necrosis factor production but not antigen-specific lymphoproliferation in acute Plasmodium falciparum malaria. J. Infect. Dis. 172, 838-844.

123. Al-Yaman, F. M., Genton, B., Clark, I. A. (1998) The ratio of reactive nitrogen intermediates to tumor necrosis factor and clinical outcome of falciparum malaria disease. Trans. R. Soc. Trop. Med. Hyg. 92, 417-420.

124. Nagamine, Y., Hayano, M., Kashiwamura, S., Okamura, H., Nakanishi, K., Krudsod, S., Wilairatana, P., Looareesuwan, S., Kojima, S. (2003) In- 
volvement of interleukin-18 in severe Plasmodium falciparum malaria. Trans. R. Soc. Trop. Med. Hyg. 97, 236-241.

125. Wroczynska, A., Nahorski, W., Bakowska, A., Pietkiewicz, H. (2005) Cytokines and clinical manifestations of malaria in adults with severe and uncomplicated disease. Int. Marit. Health 56, 103-114.

126. Walther, M., Jeffries, D., Finney, O. C., Njie, M., Ebonyi, A., Deininger, S., Lawrence, E., Ngwa-Amambua, A., Jayasooriya, S., Cheeseman, I. H., Gomez-Escobar, N., Okebe, J., Conway, D. J., Riley, E. M. (2009) Distinct roles for FOXP3 and FOXP3 CD4 T cells in regulating cellular immunity to uncomplicated and severe Plasmodium falciparum malaria. PLoS Pathog. 5, e1000364.

127. Kern, P., Hemmer, C. J., Van, D. J., Gruss, H. J., Dietrich, M. (1989) Elevated tumor necrosis factor $\alpha$ and interleukin-6 serum levels as markers for complicated Plasmodium falciparum malaria. Am. J. Med. 87, 139143.

128. Kwiatkowski, D., Hill, A. V., Sambou, I., Twumasi, P., Castracane, J., Manogue, K. R., Cerami, A., Brewster, D. R., Greenwood, B. M. (1990) TNF concentration in fatal cerebral, non-fatal cerebral, and uncomplicated Plasmodium falciparum malaria. Lancet 336, 1201-1204.

129. Yamada-Tanaka, M. S., Ferreira-da-Cruz, M. F., Alecrim, M. G., Mascarenhas, L. A., Daniel-Ribeiro, C. T. (1995) Tumor necrosis factor $\alpha$ interferon $\gamma$ and macrophage stimulating factor in relation to the severity of Plasmodium falciparum malaria in the Brazilian Amazon. Trop. Geogr. Med. 47, 282-285.

130. Prakash, D., Fesel, C., Jain, R., Cazenave, P. A., Mishra, G. C., Pied, S. (2006) Clusters of cytokines determine malaria severity in Plasmodium falciparum-infected patients from endemic areas of Central India. J. Infect. Dis. 194, 198-207.

131. Jakobsen, P. H., Morris-Jones, S., Theander, T. G., Hviid, L., Hansen, M. B., Bendtzen, K., Ridley, R. G., Greenwood, B. M. (1994) Increased plasma levels of soluble IL-2R are associated with severe Plasmodium falciparum malaria. Clin. Exp. Immunol. 96, 98-103.

132. Baptista, J. L., Vanham, G., Wery, M., Van, M. E. (1997) Cytokine levels during mild and cerebral falciparum malaria in children living in a mesoendemic area. Trop. Med. Int. Health 2, 673-679.

133. Luty, A. J., Perkins, D. J., Lell, B., Schmidt-Ott, R., Lehman, L. G., Luckner, D., Greve, B., Matousek, P., Herbich, K., Schmid, D., Weinberg, J. B., Kremsner, P. G. (2000) Low interleukin-12 activity in severe Plasmodium falciparum malaria. Infect. Immun. 68, 3909-3915.

134. Malaguarnera, L., Pignatelli, S., Musumeci, M., Simpore, J., Musumeci, S. (2002) Plasma levels of interleukin-18 and interleukin-12 in Plasmodium falciparum malaria. Parasite Immunol. 24, 489-492.

135. Chaisavaneeyakorn, S., Othoro, C., Shi, Y. P., Otieno, J., Chaiyaroj, S. C., Lal, A. A., Udhayakumar, V. (2003) Relationship between plasma interleukin-12 (IL-12) and IL-18 levels and severe malarial anemia in an area of holoendemicity in Western Kenya. Clin. Diagn. Lab. Immunol. 10, 362366.

136. Chaiyaroj, S. C., Rutta, A. S., Muenthaisong, K., Watkins, P., Na, U. M., Looareesuwan, S. (2004) Reduced levels of transforming growth factor$\beta 1$, interleukin-12 and increased migration inhibitory factor are associated with severe malaria. Acta Trop. 89, 319-327.

137. Deloron, P., Dumont, N., Nyongabo, T., Aubry, P., Astagneau, P., Ndarugirire, F., Menetrier-Caux, C., Burdin, N., Brelivet, J. C., Peyron, F. (1994) Immunologic and biochemical alterations in severe falciparum malaria: relation to neurological symptoms and outcome. Clin. Infect. Dis. 19, 480-485.

138. Maneerat, Y., Pongponratn, E., Viriyavejakul, P., Punpoowong, B., Looareesuwan, S., Udomsangpetch, R. (1999) Cytokines associated with pathology in the brain tissue of fatal malaria. Southeast Asian J. Trop. Med. Public Health 30, 643-649.

139. Armah, H. B., Wilson, N. O., Sarfo, B. Y., Powell, M. D., Bond, V. C., Anderson, W., Adjei, A. A., Gyasi, R. K., Tettey, Y., Wiredu, E. K., Tongren, J. E., Udhayakumar, V., Stiles, J. K. (2007) Cerebrospinal fluid and serum biomarkers of cerebral malaria mortality in Ghanaian children. Malar. J. 6, 147

140. Day, N. P., Hien, T. T., Schollaardt, T., Loc, P. P., Chuong, L. V., Chau, T. T., Mai, N. T., Phu, N. H., Sinh, D. X., White, N. J., Ho, M. (1999) The prognostic and pathophysiologic role of pro- and antiinflammatory cytokines in severe malaria. J. Infect. Dis. 180, 1288-1297.

141. Bream, J. H., Ping, A., Zhang, X., Winkler, C., Young, H. A. (2002) A single nucleotide polymorphism in the proximal IFN- $\gamma$ promoter alters control of gene transcription. Genes Immun. 3, 165-169.

142. Chevillard, C., Henri, S., Stefani, F., Parzy, D., Dessein, A. (2002) Two new polymorphisms in the human interferon $\gamma$ (IFN- $\gamma$ ) promoter. Eur. J. Immunogenet. 29, 53-56.

143. Cabantous, S., Poudiougou, B., Traore, A., Keita, M., Cisse, M. B., Doumbo, O., Dessein, A. J., Marquet, S. (2005) Evidence that interferon- $\gamma$ plays a protective role during cerebral malaria. J. Infect. Dis. 192, 854-860.

144. Jason, J., Archibald, L. K., Nwanyanwu, O. C., Bell, M., Jensen, R. J., Gunter, E., Buchanan, I., Larned, J., Kazembe, P. N., Dobbie, H., Jarvis, W. R. (2001) The effects of iron deficiency on lymphocyte cytokine production and activation: preservation of hepatic iron but not at all cost. Clin. Exp. Immunol. 126, 466-473.
145. Perkmann, T., Winkler, H., Graninger, W., Kremsner, P. G., Winkler, S. (2005) Circulating levels of the interleukin (IL)-4 receptor and of IL-18 in patients with Plasmodium falciparum malaria. Cytokine 29, 153-158.

146. Othoro, C., Lal, A. A., Nahlen, B., Koech, D., Orago, A. S., Udhavakumar, V. (1999) A low interleukin-10 tumor necrosis factor- $\alpha$ ratio is associated with malaria anemia in children residing in a holoendemic malaria region in Western Kenva. J. Infect. Dis. 179, 279-282.

147. Ong'echa, J. M., Lal, A. A., Terlouw, D. J., Ter Kuile, F. O., Kariuki, S. K., Udhayakumar, V., Orago, A. S., Hightower, A. W., Nahlen, B. L., Shi, Y. P. (2003) Association of interferon- $\gamma$ responses to pre-erythrocytic stage vaccine candidate antigens of Plasmodium falciparum in young Kenyan children with improved hemoglobin levels: XV. Asembo Bay Cohort Project. Am. J. Trop. Med. Hyg. 68, 590-597.

148. Fried, M., Muga, R. O., Misore, A. O., Duffy, P. E. (1998) Malaria elicits type 1 cytokines in the human placenta: IFN- $\gamma$ and TNF- $\alpha$ associated with pregnancy outcomes. J. Immunol. 160, 2523-2530.

149. Kabyemela, E. R., Fried, M., Kurtis, J. D., Mutabingwa, T. K., Duffy, P. E. (2008) Fetal responses during placental malaria modify the risk of low birth weight. Infect. Immun. 76, 1527-1534.

150. Rogerson, S. J., Brown, H. C., Pollina, E., Abrams, E. T., Tadesse, E., Lema, V. M., Molyneux, M. E. (2003) Placental tumor necrosis factor $\alpha$ but not $\gamma$ interferon is associated with placental malaria and low birth weight in Malawian women. Infect. Immun. 71, 267-270.

151. Suguitan Jr., A. L., Cadigan, T. J., Nguyen, T. A., Zhou, A., Leke, R. J., Metenou, S., Thuita, L., Megnekou, R., Fogako, J., Leke, R. G., Taylor, D. W. (2003) Malaria-associated cytokine changes in the placenta of women with pre-term deliveries in Yaounde, Cameroon. Am. J. Trop. Med. Hyg. 69, 574-581.

152. Bongfen, S. E., Torgler, R., Romero, J. F., Renia, L., Corradin, G. (2007) Plasmodium berghei-infected primary hepatocytes process and present the circumsporozoite protein to specific CD8 $+\mathrm{T}$ cells in vitro. J. Immunol. 178, 7054-7063.

153. Plebanski, M., Hannan, C. M., Behboudi, S., Flanagan, K. L., Apostolopoulos, V., Sinden, R. E., Hill, A. V. (2005) Direct processing and presentation of antigen from malaria sporozoites by professional antigenpresenting cells in the induction of CD8 T-cell responses. Immunol. Cell Biol. 83, 307-312.

154. Chakravarty, S., Cockburn, I. A., Kuk, S., Overstreet, M. G., Sacci, J. B. Zavala, F. (2007) CD8 + T lymphocytes protective against malaria liver stages are primed in skin-draining lymph nodes. Nat. Med. 13, 10351041 .

155. Del Giudice, G., Grillot, D., Renia, L., Muller, I., Corradin, G., Louis, J. A., Mazier, D., Lambert, P. H. (1990) Peptide-primed CD4+ cells and malaria sporozoites. Immunol. Lett. 25, 59-63.

156. Tsuji, M., Romero, P., Nussenzweig, R. S., Zavala, F. (1990) CD4+ cytolytic T cell clone confers protection against murine malaria. J. Exp. Med. 172, 1353-1357.

157. Tsuji, M., Mombaerts, P., Lefrancois, L., Nussenzweig, R. S., Zavala, F., Tonegawa, S. (1994) $\gamma \delta$ T cells contribute to immunity against the liver stages of malaria in $\alpha \beta$ T-cell-deficient mice. Proc. Natl. Acad. Sci. USA 91, 345-349.

158. Pied, S., Roland, J., Louise, A., Voegtle, D., Soulard, V., Mazier, D., Cazenave, P. A. (2000) Liver CD4-CD8- NK1.1+ TCR $\alpha \beta$ intermediate cells increase during experimental malaria infection and are able to exhibit inhibitory activity against the parasite liver stage in vitro. J. Immunol. 164, 1463-1469.

159. Ojo-Amaize, E. A., Vilcek, J., Cochrane, A. H., Nussenzweig, R. S. (1984) Plasmodium berghei sporozoites are mitogenic for murine T cells, induce interferon, and activate natural killer cells. J. Immunol. 133, 1005-1009.

160. Roland, J., Soulard, V., Sellier, C., Drapier, A. M., Di Santo, J. P., Cazenave, P. A., Pied, S. (2006) NK cell responses to Plasmodium infection and control of intrahepatic parasite development. J. Immunol. 177, 1229-1239

161. Lundie, R. J., de Koning-Ward, T. F., Davey, G. M., Nie, C. Q., Hansen, D. S., Lau, L. S., Mintern, J. D., Belz, G. T., Schofield, L., Carbone, F. R., Villadangos, J. A., Crabb, B. S., Heath, W. R. (2008) Blood-stage Plasmodium infection induces CD8+ T lymphocytes to parasite-expressed antigens, largely regulated by $\mathrm{CD} 8 \alpha+$ dendritic cells. Proc. Natl. Acad. Sci. USA 105, 14509-14514.

162. Miyakoda, M., Kimura, D., Yuda, M., Chinzei, Y., Shibata, Y., Honma, K., Yui, K. (2008) Malaria-specific and nonspecific activation of CD8+ T cells during blood stage of Plasmodium berghei infection. J. Immunol. 181, $1420-1428$.

163. Sinigaglia, F., Richard, J., Pink, L. (1985) Human T lymphocyte clones specific for malaria (Plasmodium falciparum) antigens. EMBO J. 4, 38193822 .

164. Behr, C., Dubois, P. (1992) Preferential expansion of V $\gamma 9 \mathrm{~V} \delta 2$ T cells following stimulation of peripheral blood lymphocytes with extracts of Plasmodium falciparum. Int. Immunol. 4, 361-366.

165. Goodier, M., Fey, P., Eichmann, K., Langhorne, J. (1992) Human peripheral blood $\gamma \delta \mathrm{T}$ cells respond to antigens of Plasmodium falciparum. Int. Immunol. 4, 33-41.

166. Jones, S. M., Goodier, M. R., Langhorne, J. (1996) The response of $\gamma \delta$ $\mathrm{T}$ cells to Plasmodium falciparum is dependent on activated CD4+ T cells and the recognition of MHC class. Immunology 89, 405-412. 
167. Goodier, M. R., Lundqvist, C., Hammarstrom, M. L., Troye-Blomberg, M., Langhorne, J. (1995) Cytokine profiles for human V $\gamma 9+\mathrm{T}$ cells stimulated by Plasmodium falciparum. Parasite Immunol. 17, 413-423.

168. Hensmann, M., Kwiatkowski, D. (2001) Cellular basis of early cytokine response to Plasmodium falciparum. Infect. Immun. 69, 2364-2371.

169. D'Ombrain, M. C., Hansen, D. S., Simpson, K. M., Schofield, L. (2007) $\gamma \delta$-T cells expressing NK receptors predominate over NK cells and conventional T cells in the innate IFN- $\gamma$ response to Plasmodium falciparum malaria. Eur. J. Immunol. 37, 1864-1873.

170. Rzepczyk, C. M., Stamatiou, S., Anderson, K., Stowers, A., Cheng, O., Saul, A., Allworth, A., McCormack, J., Whitby, M., Olive, C., Lawrence, G. (1996) Experimental human Plasmodium falciparum infections: longitudinal analysis of lymphocyte responses with particular reference to $\gamma \delta$ T cells. Scand. J. Immunol. 43, 219-227.

171. Waterfall, M., Black, A., Riley, E. (1998) $\gamma \delta+$ T cells preferentially respond to live rather than killed malaria parasites. Infect. Immun. 66, 2393-2398.

172. Behr, C., Poupot, R., Peyrat, M. A., Poquet, Y., Constant, P., Dubois, P., Bonneville, M., Fournie, J. J. (1996) Plasmodium falciparum stimuli for human $\gamma \delta \mathrm{T}$ cells are related to phosphorylated antigens of mycobacteria. Infect. Immun. 64, 2892-2896.

173. Pichyangkul, S., Saengkrai, P., Yongvanitchit, K., Stewart, A., Heppner, D. G. (1997) Activation of $\gamma \delta$ T cells in malaria: interaction of cytokines and a schizont-associated Plasmodium falciparum antigen. J. Infect. Dis. 176, 233-241.

174. Dieli, F., Troye-Blomberg, M., Farouk, S. E., Sireci, G., Salerno, A. (2001) Biology of $\gamma \delta$ T cells in tuberculosis and malaria. Curr. Mol. Med 1, 437-446.

175. Vivier, E., Tomasello, E., Baratin, M., Walzer, T., Ugolini, S. (2008) Functions of natural killer cells. Nat. Immunol. 9, 503-510.

176. Artavanis-Tsakonas, K., Riley, E. M. (2002) Innate immune response to malaria: rapid induction of IFN- $\gamma$ from human NK cells by live Plasmodium falciparum-infected erythrocytes. J. Immunol. 169, 2956-2963.

177. Baratin, M., Roetynck, S., Lepolard, C., Falk, C., Sawadogo, S., Uematsu, S., Akira, S., Ryffel, B., Tiraby, J. G., Alexopoulou, L., Kirschning, C. J., Gysin, J., Vivier, E., Ugolini, S. (2005) Natural killer cell and macrophage cooperation in MyD88-dependent innate responses to Plasmodium falciparum. Proc. Natl. Acad. Sci. USA 102, 14747-14752.

178. Newman, K. C., Korbel, D. S., Hafalla, J. C., Riley, E. M. (2006) Crosstalk with myeloid accessory cells regulates human natural killer cell interferon- $\gamma$ responses to malaria. PLoS Pathog. 2, e118.

179. Artavanis-Tsakonas, K., Eleme, K., McQueen, K. L., Cheng, N. W., Parham, P., Davis, D. M., Riley, E. M. (2003) Activation of a subset of human NK cells upon contact with Plasmodium falciparum-infected erythrocytes. J. Immunol. 171, 5396-5405.

180. Korbel, D. S., Newman, K. C., Almeida, C. R., Davis, D. M., Riley, E. M. (2005) Heterogeneous human NK cell responses to Plasmodium falciparum-infected erythrocytes. J. Immunol. 175, 7466-7473.

181. Korbel, D. S., Norman, P. J., Newman, K. C., Horowitz, A., Gendzekhadze, K., Parham, P., Riley, E. M. (2009) Killer Ig-like receptor (KIR) genotype predicts the capacity of human KIR-positive CD56dim NK cells to respond to pathogen-associated signals. J. Immunol. 182, 6426-6434.

182. Mavoungou, E., Held, J., Mewono, L., Kremsner, P. G. (2007) A Duffy binding-like domain is involved in the NKp30-mediated recognition of Plasmodium falciparum-parasitized erythrocytes by natural killer cells. J. Infect. Dis. 195, 1521-1531.

183. Coban, C., Igari, Y., Yagi, M., Reimer, T., Koyama, S., Aoshi, T., Ohata, K., Tsukui, T., Takeshita, F., Sakurai, K., Ikegami, T., Nakagawa, A., Horii, T., Nunez, G., Ishii, K. J., Akira, S. (2010) Immunogenicity of whole-parasite vaccines against Plasmodium falciparum involves malarial hemozoin and host TLR9. Cell Host Microbe 7, 50-61.

184. Parroche, P., Lauw, F. N., Goutagny, N., Latz, E., Monks, B. G., Visintin, A., Halmen, K. A., Lamphier, M., Olivier, M., Bartholomeu, D. C., Gazzinelli, R. T., Golenbock, D. T. (2007) Malaria hemozoin is immunologically inert but radically enhances innate responses by presenting malaria DNA to Toll-like receptor 9. Proc. Natl. Acad. Sci. USA 104, 19191924.

185. Currier, J., Sattabongkot, J., Good, M. F. (1992) "Natural" T cells responsive to malaria: evidence implicating immunological cross-reactivity in the maintenance of TCR $\alpha \beta+$ malaria-specific responses from nonexposed donors. Int. Immunol. 4, 985-994.

186. Hermsen, C. C., Konijnenberg, Y., Mulder, L., Loé, C., van Deuren, M., van der Meer, J. W., van Mierlo, G. J., Eling, W. M., Hack, C. E., Sauerwein, R. W. (2003) Circulating concentrations of soluble granzyme A and B increase during natural and experimental Plasmodium falciparum infections. Clin. Exp. Immunol. 132, 467-472.

187. Zevering, Y., Amante, F., Smillie, A., Currier, J., Smith, G., Houghten, R. A., Good, M. F. (1992) High frequency of malaria-specific T cells in non-exposed humans. Eur. J. Immunol. 22, 689-696.

188. Dick, S., Waterfall, M., Currie, J., Maddy, A., Riley, E. (1996) Naive human $\alpha \beta$ T cells respond to membrane-associated components of malaria-infected erythrocytes by proliferation and production of interferon- $\gamma$. Immunology 88, 412-420.
189. Scragg, I. G., Hensmann, M., Bate, C. A., Kwiatkowski, D. (1999) Early cytokine induction by Plasmodium falciparum is not a classical endotoxinlike process. Eur. J. Immunol. 29, 2636-2644.

190. Ndungu, F. M., Sanni, L., Urban, B., Stephens, R., Newbold, C. I., Marsh, K., Langhorne, J. (2006) CD4 T cells from malaria-nonexposed individuals respond to the CD36-binding domain of Plasmodium falciparum erythrocyte membrane protein-1 via an MHC class II-TCR-independent pathway. J. Immunol. 176, 5504-5512.

191. Good, M. F. (1994) Immunological responses from non-exposed donors to malaria antigens: implications for immunity and pathology. Immunol. Lett. 41, 123-125.

192. Wyler, D. J., Oppenheim, J. J. (1974) Lymphocyte transformation in human Plasmodium falciparum malaria. J. Immunol. 113, 449-454.

193. Trove-Blomberg, M., Andersson, G., Stoczkowska, M., Shabo, R., Romero, P., Patarroyo, M. E., Wigzell, H., Perlmann, P. (1985) Production of IL 2 and IFN- $\gamma$ by T cells from malaria patients in response to Plasmo dium falciparum or erythrocyte antigens in vitro. J. Immunol. 135, 3498 3504 .

194. Chizzolini, C., Grau, G. E., Geinoz, A., Schrijvers, D. (1990) T lymphocyte interferon- $\gamma$ production induced by Plasmodium falciparum antigen is high in recently infected non-immune and low in immune subjects. Clin. Exp. Immunol. 79, 95-99.

195. Ramharter, M., Willheim, M., Winkler, H., Wahl, K., Lagler, H., Graninger, W., Winkler, S. (2003) Cytokine profile of Plasmodium falciparum-specific T cells in non-immune malaria patients. Parasite Immunol. 25, 211-219.

196. Dorfman, J. R., Bejon, P., Ndungu, F. M., Langhorne, J., Kortok, M. M., Lowe, B. S., Mwangi, T. W., Williams, T. N., Marsh, K. (2005) B cell memory to 3 Plasmodium falciparum blood-stage antigens in a malariaendemic area. J. Infect. Dis. 191, 1623-1630.

197. Kinyanjui, S. M., Conway, D. J., Lanar, D. E., Marsh, K. (2007) IgG antibody responses to Plasmodium falciparum merozoite antigens in Kenyan children have a short half-life. Malar. J. 6, 82.

198. Akpogheneta, O. J., Duah, N. O., Tetteh, K. K., Dunyo, S., Lanar, D. E., Pinder, M., Conway, D. J. (2008) Duration of naturally acquired antibody responses to blood-stage Plasmodium falciparum is age dependent and antigen specific. Infect. Immun. 76, 1748-1755.

199. Achtman, A. H., Bull, P. C., Stephens, R., Langhorne, J. (2005) Longevity of the immune response and memory to blood-stage malaria infection. Curr. Top. Microbiol. Immunol. 297, 71-102.

200. Migot, F., Chougnet, C., Raharimalala, L., Astagneau, P., Lepers, J. P., Deloron, P. (1993) Human immune responses to the Plasmodium falciparum ring-infected erythrocyte surface antigen (Pf155/RESA) after a decrease in malaria transmission in Madagascar. Am. J. Trop. Med. Hyg. 48, 432-439.

201. Zevering, Y., Khamboonruang, C., Rungruengthanakit, K., Tungviboonchai, L., Ruengpipattanapan, J., Bathurst, I., Barr, P., Good, M. F. (1994) Life-spans of human T-cell responses to determinants from the circumsporozoite proteins of Plasmodium falciparum and Plasmodium vivax. Proc. Natl. Acad. Sci. USA 91, 6118-6122.

202. Rhee, M. S., Akanmori, B. D., Waterfall, M., Riley, E. M. (2001) Changes in cytokine production associated with acquired immunity to Plasmodium falciparum malaria. Clin. Exp. Immunol. 126, 503-510.

203. Chizzolini, C., Geinoz, A., Schrijvers, D. (1990) Interleukin-2 reverses T cell unresponsiveness to Plasmodium falciparum-antigen in malaria immune subjects. Cell. Immunol. 128, 1-10.

204. Torcia, M. G., Santarlasci, V., Cosmi, L., Clemente, A., Maggi, L., Mangano, V. D., Verra, F., Bancone, G., Nebie, I., Sirima, B. S., Liotta, F., Frosali, F., Angeli, R., Severini, C., Sannella, A. R., Bonini, P., Lucibello, M., Maggi, E., Garaci, E., Coluzzi, M., Cozzolino, F., Annunziato, F., Romagnani, S., Modiano, D. (2008) Functional deficit of T regulatory cells in Fulani, an ethnic group with low susceptibility to Plasmodium falciparum malaria. Proc. Natl. Acad. Sci. USA 105, 646-651.

205. Finney, O. C., Nwakanma, D., Conway, D. J., Walther, M., Riley, E. M. (2009) Homeostatic regulation of $\mathrm{T}$ effector to Treg ratios in an area of seasonal malaria transmission. Eur. J. Immunol. 39, 1288-1300.

206. Finney, O. C., Riley, E. M., Walther, M. (2010) Regulatory T cells in malaria-friend or foe? Trends Immunol. 31, 63-70.

207. Casares, S., Richie, T. L. (2009) Immune evasion by malaria parasites: a challenge for vaccine development. Curr. Opin. Immunol. 21, 321-330.

208. Troye-Blomberg, M., Perlmann, H., Patarroyo, M. E., Perlmann, P. (1983) Regulation of the immune response in Plasmodium falciparum malaria. II. Antigen specific proliferative responses in vitro. Clin. Exp. Immunol. 53, 345-353.

209. Theander, T. G., Bygbjerg, I. C., Andersen, B. J., Jepsen, S., Kharazmi, A., Odum, N. (1986) Suppression of parasite-specific response in Plasmo dium falciparum malaria. A longitudinal study of blood mononuclear cell proliferation and subset composition. Scand. J. Immunol. 24, 73-81.

210. Riley, E. M., Andersson, G., Otoo, L. N., Jepsen, S., Greenwood, B. M. (1988) Cellular immune responses to Plasmodium falciparum antigens in Gambian children during and after an acute attack of falciparum malaria. Clin. Exp. Immunol. 73, 17-22.

211. Luty, A. J., Bongartz, M., Rezbach, P., Faucher, J. F., Hollingdale, M. R., Kremsner, P. G. (2001) Plasmodium falciparum liver-stage antigen-1 pep- 
tide-specific interferon- $\gamma$ responses are not suppressed during uncomplicated malaria in African children. Eur. Cytokine Netw. 12, 647-653.

212. Otoo, L. N., Riley, E. M., Menon, A., Byass, P., Greenwood, B. M.

(1989) Cellular immune responses to Plasmodium falciparum antigens in children receiving long term anti-malarial chemoprophylaxis. Trans. $R$. Soc. Trop. Med. Hyg. 83, 778-782.

213. O'Leary, J. G., Goodarzi, M., Drayton, D. L., von Andrian, U. H. (2006) $\mathrm{T}$ cell- and $\mathrm{B}$ cell-independent adaptive immunity mediated by natural killer cells. Nat. Immunol. 7, 507-516.

214. Long, B. R., Michaelsson, J., Loo, C. P., Ballan, W. M., Vu, B. A., Hecht, F. M., Lanier, L. L., Chapman, J. M., Nixon, D. F. (2008) Elevated frequency of $\gamma$ interferon-producing NK cells in healthy adults vaccinated against influenza virus. Clin. Vaccine Immunol. 15, 120-130.

215. Graves, P., Gelband, H. (2006) Vaccines for preventing malaria (bloodstage). Cochrane Database Syst. Rev. CD006199.

216. Graves, P., Gelband, H. (2006) Vaccines for preventing malaria (preerythrocytic). Cochrane Database Syst. Rev. CD006198.

217. Graves, P., Gelband, H. (2006) Vaccines for preventing malaria (SPf66) Cochrane Database Syst. Rev. CD005966.

218. Remarque, E. J., Faber, B. W., Kocken, C. H., Thomas, A. W. (2008) Apical membrane antigen 1: a malaria vaccine candidate in review. Trends Parasitol. 24, 74-84.

219. Doolan, D. L., Dobano, C., Baird, J. K. (2009) Acquired immunity to malaria. Clin. Microbiol. Rev. 22, 13-36 (Table.).

220. Zola, H. (1997) The development of antibody responses in the infant Immunol. Cell Biol. 75, 587-590.

221. Lewinsohn, D. A., Gennaro, M. L., Scholvinck, L., Lewinsohn, D. M. (2004) Tuberculosis immunology in children: diagnostic and therapeutic challenges and opportunities. Int. J. Tuberc. Lung Dis. 8, 658-674.

222. Baird, J. K. (1998) Age-dependent characteristics of protection v. susceptibility to Plasmodium falciparum. Ann. Trop. Med. Parasitol. 92, 367-390.

223. Zuckerman, A., Yoeli, M. (1954) Age and sex as factors influencing Plasmodium berghei infections in intact and splenectomized rats. J. Infect. Dis. 94, 225-236.

224. Smalley, M. E. (1975) The nature of age immunity to Plasmodium berghei in the rat. Parasitology 71, 337-347.

225. Adam, E., Pierrot, C., Lafitte, S., Godin, C., Saoudi, A., Capron, M., Khalife, J. (2003) The age-related resistance of rats to Plasmodium berghei infection is associated with differential cellular and humoral immune responses. Int. J. Parasitol. 33, 1067-1078.

226. Winkler, S., Willheim, M., Baier, K., Graninger, W., Kremsner, P. G. (1999) Frequency of cytokine-producing CD4-CD8- peripheral blood mononuclear cells in patients with Plasmodium falciparum malaria. Eur. Cytokine Netw. 10, 155-160.

227. Bucci, K., Kastens, W., Hollingdale, M. R., Shankar, A., Alpers, M. P. King, C. L., Kazura, J. W. (2000) Influence of age and HLA type on interferon- $\gamma($ IFN- $\gamma$ ) responses to a naturally occurring polymorphic epitope of Plasmodium falciparum liver stage antigen-1 (LSA-1). Clin. Exp. Immunol. 122, 94-100.

228. Ramharter, M., Winkler, H., Kremsner, P. G., Adegnika, A. A., Willheim M., Winkler, S. (2005) Age-dependency of Plasmodium falciparum-specific and non-specific $\mathrm{T}$ cell cytokine responses in individuals from a malariaendemic area. Eur. Cytokine Netw. 16, 135-143.

229. Baird, J. K., Jones, T. R., Danudirgo, E. W., Annis, B. A., Bangs, M. J., Basri, H., Purnomo, Masbar, S. (1991) Age-dependent acquired protection against Plasmodium falciparum in people having two years exposure to hyperendemic malaria. Am. J. Trop. Med. Hyg. 45, 65-76.

230. Bousema, J. T., Roeffen, W., van der Kolk, M., de Vlas, S. J., van de Vegte-Bolmer, M., Bangs, M. J., Teelen, K., Kurniawan, L., Maguire, J. D., Baird, J. K., Sauerwein, R. W. (2006) Rapid onset of transmissionreducing antibodies in Javanese migrants exposed to malaria in Papua, Indonesia. Am. J. Trop. Med. Hyg. 74, 425-431.

231. Murhandarwati, E. E., Black, C. G., Wang, L., Weisman, S., KoningWard, T. F., Baird, J. K., Tjitra, E., Richie, T. L., Crabb, B. S., Coppel, R. L. (2008) Acquisition of invasion-inhibitory antibodies specific for the 19-kDa fragment of merozoite surface protein 1 in a transmigrant population requires multiple infections. J. Infect. Dis. 198, 1212-1218.

232. Deloron, P., Chougnet, C. (1992) Is immunity to malaria really shortlived? Parasitol. Today 8, 375-378.

\section{KEY WORDS:}

human $\cdot$ falciparum $\cdot$ cytokine $\cdot$ innate $\cdot$ adaptive $\cdot$ vaccine 